School of Finance

University of St.Gallen

THE IMPACT OF CREDIT INFORMATION SHARING ON INTEREST RATES

THOMAS GIETZEN

WORKING PAPERS ON FINANCE No. 2016/12

SWISS INSTITUTE OF BANKING AND FINANCE (S/BF - HSG)

JUNE 2016 


\title{
The Impact of Credit Information Sharing on Interest Rates - Working Paper -
}

\author{
Thomas Gietzen*
}

\begin{abstract}
I study the impact of information sharing among banks on interest rates borrowers pay. To identify the effect of credit information sharing, I exploit a particular feature of the introduction of an information sharing system in an African banking market. Banks started to report borrowers to the new system more than a year before they began to actively use the data to screen applicants. Hence, this study is the first to directly control for compositional changes in the borrower pool by combining a control period during which no information was shared among banks with a loan-level data source that facilitates tracing borrowers who switch banks. Results lend great support to the idea that information sharing efficiently mitigates adverse selection problems. Successful repeated borrowers are able to obtain cheaper follow-up loans when information is actively shared among banks and borrowers who switch institutions profit most from the reduction in adverse selection. At the same time, as banks loose their ability to hold-up successful borrowers for their second loan, first-time credit starts to be more expensive, even though this effect is strongly outweighed by the cost reduction for follow-up loans.
\end{abstract}

Keywords: Credit Information Sharing, Credit Registry, Interest Rates, Switching

${ }^{*}$ KfW Development Bank, Evaluation Department, Palmengartenstrasse 5-9, 60325 Frankfurt am Main, Germany, Thomas.Gietzen@kfw.de, +49(0)69-74316239 and Swiss Institute of Banking and Finance, University of St.Gallen

Disclaimer: Any views or opinions presented in this paper are solely those of the author and do not necessarily represent those of the company. 


\section{Introduction}

Asymmetrically distributed information and problems of adverse selection are inherent to bank lending because borrowers usually know more about their undertakings than banks do. To mitigate this problem banks screen their borrowers before granting loans. Yet, banks also learn about borrowers over the course of a bank-borrower relationship by observing their repayment behavior. It has been regulatory practice in most developed banking markets to have banks share that information about their borrowers among each other and more and more regulators worldwide have introduced credit information sharing systems to do so. Even recent years have witnessed a tremendous increase in the existence of such systems. In 2007, 54 countries in the World Bank's Doing Business Report had no active credit information sharing system in place, while by 2015 this number has more than halved to 26. Sharing credit information means that much of the details on a bankborrower relationship is no longer exclusive to the lending bank. This shift in the distribution of information has strong implications for the cost and availability of credit since the informational advantage of a bank over its competitors is a typical source of bank rents (informational hold-up). Theoretically, credit information sharing makes it easier for competing banks to catch sight of each others good and bad borrowers. Successful borrowers that try to switch banks must no longer be afraid of facing an adverse selection premium because of being pooled with unsuccessful borrowers at other banks. This strips the lending bank of the possibility to charge an informational premium to its successful borrowers. Loosing that premium, however, renders reaching out to new borrowers less attractive for banks in the first place slacking competition for borrowers without a credit history.

In this paper, I study these effects of information sharing on bank lending empirically and overcome a data related trade-off that has impeded previous empirical studies on credit information sharing. I use the introduction of a credit information sharing system in a major African banking market and exploit a particular feature of the introduction of the new system for identification: Although the credit information sharing system was introduced in 
late 2008 and borrowers started to be recorded in it, banks were not actively using the system at the screening stage for new loans until mid-2010. The time window during which loans were reported by banks and were recorded in the system, but when credit was given without information being shared effectively, serves as a control time period. This special feature of the system makes this study the first to be able to establish a no-information-sharing control group and at the same time control for compositional bias by tracing single borrowers when they switch to other banks.

The results from combining the virtue of both features provide strong evidence that credit information sharing reduces adverse selection problems and informational hold-up at the insider bank. When no information is actively shared among banks, both, borrowers who switch to an outside bank and borrowers who roll over existing loans at the insider bank, face an upward sloping interest rate profile. On average, the premium they pay on their second loan renders the follow-up loans even more expensive than the initial loan. When credit information is shared actively, on the other hand, the interest rate profile from the first to the second loan turns downward sloping. This is because successful repeated borrowers must no longer be afraid to be pooled with unsuccessful borrowers at outside banks and are able to obtain cheaper follow-up loans. This effect of information sharing is stronger for borrowers who actually switch to other banks. Outsider banks tend to undercut the incumbent bank more strongly when information is being shared actively, because fears of poaching a bad borrower are mitigated by the information shared. The downside of this cost reduction for follow-up loans is an increase in the costs for initial loans. As it gets harder for banks to hold on to good borrowers after the initial loan, they compete less fiercely for new borrowers without a credit history, increasing their costs of credit. The economic size of the effect on initial loans' interest rates is, however, much smaller than the reduction of interest rates successful borrowers enjoy for follow-up loans.

Macro level studies tend to find favorable impacts of credit information sharing systems. Jappelli and Pagano (2002) show that countries with active 
credit information sharing systems feature higher lending volumes and lower credit risk and Djankov, McLiesh, and Shleifer (2007) demonstrate that credit information sharing systems go hand in hand with higher private credit to GDP ratios. Brown, Jappelli, and Pagano (2009) use a panel data approach and firm-level survey data on self-reported costs of credit and find that in particular opaque firms profit from cheaper and more easily available credit under regimes of credit information sharing. They also conclude that the overall composition of borrowers in a market likely changes when an information sharing system is introduced.

Previously, most studies at the loan level have estimated the effect of information sharing looking at a single bank's portfolio around the introduction of an information sharing system. Behr and Sonnekalb (2012) do so for a commercial bank's portfolio around the introduction of a credit information sharing system in Albania in 2008. They find that information sharing does significantly reduce the likelihood of default but find no effect on interest rates. Similarly, Bos, Haas, and Millone (2015) study the effect of the introduction of an information sharing system on a lender's portfolio in Bosnia and Herzegovina using matching techniques to compare the before and after portfolio of the bank. Bos, Haas, and Millone (2015) also note that credit information sharing should have a stronger effect in more competitive areas. Indeed, the authors find evidence that the introduction of the credit information sharing system led to more costly credit for first-time borrowers but lower interest rates for repeated borrowers, particularly in highly competitive areas. Janvry, McIntosh, and Sadoulet (2010) look at the staggered entry of a Guatemalan microfinance lender's branches to a system of credit information sharing and subsequent borrower training sessions and find that the average lending volume increases. While they argue that interest rates should decrease in the long-run, interest rates are fixed over the short-run horizon of their study.

Despite offering a clean identification strategy, comparing a bank's portfolio before and after the introduction of a information sharing system, is prone to compositional changes in the bank's borrower pool. A bank could by 
chance experience an influx of borrowers from other banks (possibly triggered by the existence of the new system) who are above the average risk in the portfolio and drive up the average interest rate but nevertheless manage to secure a cheaper loan individually than at their old bank. Whenever these composition effects are related to unobservable characteristics and cannot be controlled for they will lead to biased estimates.

One way of controlling for compositional changes is to use data from an information sharing mechanism itself, because borrowers can then be tracked when switching institutions and the researcher is able to compare previous and new interest rates for every individual. To my knowledge, the only paper that is able to trace borrowers switching banks and that, at the same time actually observes the cost of credit is Ioannidou and Ongena (2010) that uses comprehensive data from the Bolivian public credit registry. Ioannidou and Ongena (2010) unveil an interesting pattern in interest rates. Firms that switch banks obtain a significantly lower interest rate at their new bank in the beginning and the new bank keeps on reducing the rate up until a point where it sharply increases it and borrowers become inclined to switch again. The identification strategy in Ioannidou and Ongena (2010) is based on the fact that the Bolivian credit registry does not capture a borrower's full history but only a short time window and some extent of asymmetric information is left in the market. Ioannidou and Ongena (2010) exploit this feature to show that the information sharing cut-off point is relevant to the observed pattern of cost of credit. However, it is an intricate task to find a clean no-information-sharing control group using data from an information sharing system because usually no data source that would cover all banks (at the loan-level) is available before the start of the information sharing system itself. By the same token, Ioannidou and Ongena 2010 do not observe loans that were given without recent payment history information being shared by the banks.

The results from this paper that combines the virtues of a clean control group with a sound approach to tackle compositional bias add to the growing literature that points to the desirable effects of credit information sharing 
among banks. A reduction in adverse selection in the market rewards timely repaying borrowers and facilitates more efficient bank-borrower matches. This holds even without taking into account the anti moral hazard effect of information sharing yet and shows that the recent surge in the existence of credit information sharing systems is to the advantage of borrowers in opaque financial markets.

\section{Hypotheses}

The theory distinguishes three channels by which information sharing affects the cost of credit. Firstly, credit information sharing is expected to curb moral hazard on the borrower side. Padilla and Pagano (1997) show that borrowers knowing they are informationally captured by their current bank may reduce their effort to repay their loan, because much of the profit will be appropriated by the bank. In a related model, Padilla and Pagano (2000) show that whenever banks share information about past defaults, borrowers exert higher effort for the fear of being known to all banks as a defaulter.

Secondly, credit information sharing impacts borrowers' incentives to strategically over-borrow. In their model, Bennardo, Pagano, and Piccolo (2014) show that in a setting of borrowing from multiple banks and limited liability, borrowers (and lenders) may have a strategic incentive to over-borrow (overlend), that forces lenders to engage in credit-rationing and/or higher interest rates to protect themselves against this behavior. Bennardo, Pagano, and Piccolo (2014) show that in active markets, information sharing among banks reduces incentives for borrowers to over-borrow and consequently reduces credit rationing and interest rates charged by lenders.

Finally, the anti-adverse selection channel, I focus on in this paper, was popularized by Sharpe (1990) and Thadden (2004) who show that informational advantages of an incumbent lender over competing lenders can create lock-in effects because borrowers will find it hard to demonstrate creditworthiness to an outsider bank (informational hold-up). This informational capture is a source of bank rents because held-up borrowers are charged higher than 
competitive interest rates for the fear of being pooled with bad borrowers at an outsider bank. Credit information sharing alleviates this lock-in effect by mitigating adverse selection concerns and thus introduces competition into later lending rounds as borrowers can demonstrate their successful history to other lenders. However, if banks can more easily identify good borrowers in later lending rounds, poaching activities can be targeted towards the best borrowers. In their models Gehrig and Stenbacka (2007) and Bouckaert and Degryse (2004) show that, as it gets harder to extract rents from borrowers in later periods, first period competition for market shares decreases which implies higher rates for new borrowers without a history ${ }^{1}$

\section{The Model}

I present an amended version of the model by Gehrig and Stenbacka (2007) to illustrate the mechanisms behind the anti-adverse selection channel and derive testable hypotheses about the impact of active information sharing on interest rates. One feature of the original model is that it assumes success rates of strictly zero for risky borrowers which leads to the same prediction for the interest rates of follow up loans no matter if information is shared among banks or not. Here, I introduce a non-zero default probability for risky borrowers to allow for a richer set of predictions, i.e. changing interest rates for follow up loans (Gehrig and Stenbacka (2007) mention, but do not solve, this amended version of the model in their paper.).

In the model there are two banks, $\mathrm{A}$ and $\mathrm{B}$, competing via interest rates in a two period model of the banking market. The banks face costs of funding of $R_{0}$. There are two types of borrowers, highly-talented (the good borrowers) and lowly-talented (the bad borrowers) who require bank borrowing to finance their undertakings that yield a cash-flow of $\nu$ with probability $\pi_{h}$ and $\pi_{l}$ respectively $\left(1>\pi_{h}>\pi_{l}>0\right)$. Long-term contracts are ruled out by

\footnotetext{
${ }^{1}$ Karapetyan and Stacescu $(2014)$ develop a mathematically rigorous model similar to Sharpe (1990) and Thadden (2004) in which banks can invest in additional private information that needs not to be shared. They suggest that in the wake of information sharing this fully private information becomes more valuable and banks will start to invest more into private information gathering.
} 
assumption. Borrowers consume any free cash flow immediately, i.e. there are no savings to finance an undertaking in period 2. The share of good borrowers in the total borrower pool $0<\lambda<1$ is common knowledge. Before the first lending round starts, banks do not know about the type of borrower they are facing. The lending bank (the insider bank), however, receives a perfect signal about the borrower type after the first round of lending. The signal is completely unobservable by the outsider bank that did not lend to the borrower. In period 2 , banks will thus be able to price differentiate between their existing borrowers from period 1 and new borrowers with the rates $R_{i}^{2}, Q_{i}^{2}, i=A, B$. Borrowers who switch from their initial bank in period 1 to the other bank in period 2 face idiosyncratic switching costs. The switching costs represent both the loss of foregone relationship benefits at the insider bank but also transactual costs of switching. I follow the standard assumption that borrowers learn about their switching costs only at the beginning of period 2, i.e. during the first interaction with a lender, so that the initial choice of lender cannot be conditioned on the switching costs. Switching costs are only known to the borrower, are heterogeneous and are represented by a uniform distribution on the interval $[0, \bar{b}]$. The density function for the switching costs is $f(b)=1 / \bar{b}$ for $b \in[0, \bar{b}]$. In period 1 banks compete for the total pool of borrowers, while in period 2 banks offer optimal rates to their borrowers from period 1 (the captured borrowers) and to the borrowers who have borrowed from the other bank in period 1 and then may switch banks (the poached borrowers). I assume that despite the non-zero success probability for bad borrowers, the expected return from lending to them is always negative. Hence, the insider bank will not offer second round financing to bad borrowers. I also assume that bad borrowers will always want to switch because private benefits from borrowing exceed maximum switching costs. The market share of the two banks acquired in period 1 is denoted by $\mu_{i}, i=A, B$. The game is solved by backwards induction for both the case when information about observed borrower types from period 1 is shared with the outsider bank in period 2 (information sharing) and when it not (no information sharing). 
Good borrowers in period 2 will prefer to switch banks if the rate at the outsider bank plus the switching costs are strictly lower than the rate at the insider bank. For an indifferent good borrower who borrowed from Bank $i$ the following will hold:

$$
\pi_{h} Q_{j}^{2}+\hat{b}_{i j}^{h}=\pi_{h} R_{i}^{2} \Leftrightarrow \hat{b}_{i j}^{h}=\pi_{h}\left(R_{i}^{2}-Q_{j}^{2}\right)
$$

The profits from lending to the different borrower groups in period 2 are then given by the following:

1. captured good:

$$
\mu_{i} \lambda\left(\pi_{h} R_{i}^{2}-R_{0}\right) \int_{\pi_{h}\left(R_{i}^{2}-Q_{j}^{2}\right)}^{\bar{b}}
$$

2. poached good:

$$
\mu_{j} \lambda\left(\pi_{h} Q_{i}^{2}-R_{0}\right) \int_{0}^{\pi_{h}\left(R_{j}^{2}-Q_{i}^{2}\right)}
$$

3. poached bad:

$$
\mu_{j}(1-\lambda)\left(\pi_{l} Q_{i}^{2}-R_{0}\right) \int_{0}^{\bar{b}}
$$

\section{No Information Sharing (Period 2)}

Next, I solve the model for the initial market share of bank A $\left(\mu_{A}\right)$ for the case when no information about borrower types is shared by the insider bank after period 1 (the case for $\mu_{B}$ is symmetrical). Bank A maximizes its profits from the good borrowers from $\mu_{A}$, i.e. the profits from the captured good borrowers from period 1 (it does not lend to its own bad borrowers from period 1):

$$
\max _{R_{A}^{2}} \mu_{A} \lambda\left(\pi_{h} R_{A}^{2}-R_{0}\right) * \frac{1}{\bar{b}}\left[\bar{b}-\pi_{h}\left(R_{A}^{2}-Q_{B}^{2}\right)\right]
$$


Bank B also maximizes the profits from $\mu_{A}$ but has to factor in poached bad borrowers as well:

$$
\max _{Q_{B}^{2}} \mu_{A} \lambda\left(\pi_{h} Q_{B}^{2}-R_{0}\right) * \frac{1}{\bar{b}}\left(\pi_{h}\left(R_{A}^{2}-Q_{B}^{2}\right)\right)+\mu_{A}(1-\lambda)\left(\pi_{l} Q_{B}^{2}-R_{0}\right)
$$

It can then be shown that the optimal period 2 interest rates under no information sharing (and for identical banks) are $2^{2}$;

$$
\stackrel{N S}{R_{A}^{2}}=\frac{3 R_{0}+\Omega+2 \bar{b}}{3 \pi_{h}} \text { and } \stackrel{N S}{Q_{B}^{2}}=\frac{3 R_{0}+2 \Omega+\bar{b}}{3 \pi_{h}} \text { with } \Omega=\frac{\bar{b}(1-\lambda) \pi_{l}}{\lambda \pi_{h}}
$$

The difference between the insider and the outsider rate is:

$$
\begin{aligned}
& N S \\
& R_{A}^{2}
\end{aligned}-\stackrel{N S}{Q_{B}^{2}}=\frac{\bar{b}-\Omega}{3 \pi_{h}}=\bar{b}-\bar{b} * \frac{(1-\lambda) \pi_{l}}{\lambda \pi_{h}}
$$

I.e. the outsider will find it optimal to choose a rate below the insider's rate if the share of lowly talented borrowers in the borrower pool is not too high (given the respective difference in the success probability) $!^{3}$

$$
\frac{(1-\lambda) \pi_{l}}{\lambda \pi_{h}}<1 \Rightarrow \stackrel{N S}{Q_{B}^{2}}<\stackrel{N S}{R_{A}^{2}}
$$

Additionally, the outsider undercuts the insider more strongly if the share of good borrowers in the pool is high. The reason for that can be inferred from the profit maximization problem of the outsider. If the share of good borrowers $(\lambda)$ decreases, the outsider puts more emphasis on the losses on the poached bad (the second part of the sum). The outsider reduces those losses by charging a relatively higher rate to the poached borrowers and accepting to poach less borrowers.

\footnotetext{
${ }^{2}$ The derivations are available upon request.

${ }^{3}$ It can be shown that there is always some minimum level of good borrowers in the pool of borrowers that will assure positive profits for the outsider bank from poaching under no information sharing. Under this condition switching will be an equilibrium phenomenon. The non-negative-profit condition is more complex than in the original model of Gehrig and Stenbacka (2007) but the intuition remains the same: Switching will only occur if the adverse selection problems under no information sharing are not too severe.
} 


\section{Information Sharing (Period 2)}

Under information sharing bank A faces the exact same profit maximization problem as before. However, bank B knows about bad borrowers and does not lend to them and thus faces no losses from poached bad borrowers:

$$
\max _{Q_{B}^{2}} \mu_{A} \lambda\left(\pi_{h} Q_{B}^{2}-R_{0}\right) * \frac{1}{\bar{b}}\left(\pi_{h}\left(R_{A}^{2}-Q_{B}^{2}\right)\right)
$$

It can be shown that the optimal period 2 interest rates under information sharing are:

$$
\stackrel{S}{R_{A}^{2}}=\frac{3 R_{0}+2 \bar{b}}{3 \pi_{h}} \text { and } \stackrel{S}{Q_{B}^{2}}=\frac{3 R_{0}+\bar{b}}{3 \pi_{h}}
$$

Under information sharing both the second-period rate charged by the insider and the outsider go down: $\stackrel{S}{Q_{B}^{2}}<\stackrel{N S}{Q_{B}^{2}}$ and $\left.\stackrel{S}{R_{A}^{2}}<\stackrel{N S}{R_{A}^{2}}\right]_{4}$ I I also find that $\stackrel{S}{Q_{B}^{2}}<\stackrel{S}{R_{A}^{2}}$, i.e under information sharing, again, the outsider bank undercuts the insider bank. Assuming that switching does indeed occur in equilibrium (i.e. the share of lowly talented borrowers is not too high), the difference between the insider and the outsider rates is wider under a regime of information sharing because $\stackrel{S}{R_{A}^{2}}-\stackrel{S}{Q_{B}^{2}}=\frac{\bar{b}}{3 \pi_{h}}>\stackrel{N S}{R_{A}^{2}}-\stackrel{N S}{Q_{B}^{2}}=\frac{\bar{b}-\Omega}{3 \pi_{h}}$. While the outsider bank's poaching activities are held in check by the adverse selection problem under no information sharing, it must not fear to poach bad borrowers any longer when information is shared. That is why the outsider finds it optimal to undercut the insider more strongly.

\section{First Period}

In period 1 the banks set an interest rate that - given the optimal choices of interest rates in period 2 - leads to an initial market share that maximizes total profits over both periods. Total profits of bank A (again bank B is symmetrical) over both periods are given by the following profit function. The parts of the sum represent the second period profits on the captured

\footnotetext{
${ }^{4}$ This is where the results from this model deviate from the original version in which bad borrowers had a zero probability of success. The original model predicts that secondperiod interest rates are invariant to whether information is shared or not.
} 
good borrowers, the second period profits on the poached good borrowers, the second period losses on the poached bad borrowers (under no information sharing), the first period profits on the good borrowers and the first period gain or loss on the bad borrowers:

$$
\begin{aligned}
& \Pi_{A}^{2}=\delta \mu_{A} \lambda\left(\pi_{h} R_{A}^{2}-R_{0}\right) \int_{\pi_{h}\left(R_{A}^{2}-Q_{B}^{2}\right)}^{\bar{b}}+\delta\left(1-\mu_{A}\right) \lambda\left(\pi_{h} Q_{A}^{2}-R_{0}\right) \int_{0}^{\pi_{h}\left(R_{B}^{2}-Q_{A}^{2}\right)} \\
& +\delta\left(1-\mu_{A}\right)(1-\lambda)\left(\pi_{h} Q_{A}^{2}-R_{0}\right) \int_{0}^{\bar{b}}+\mu_{A} \lambda\left(\pi_{h} R_{A}^{1}-R_{0}\right)+\mu_{A}(1-\lambda)\left(\pi_{l} R_{A}^{1}-R_{0}\right)
\end{aligned}
$$

Applying the optimal second period interest rates to the profit function under no information sharing and information sharing respectively, I find the optimal first period interest rates for bank A (and similar for bank B) to be:

$$
\begin{gathered}
R_{A, B}^{N S}=\frac{-\delta \lambda \frac{1}{3}\left(\Omega+\bar{b}+\frac{\Omega^{2}}{\bar{b}}\right)+\delta(1-\lambda)\left[\frac{\pi_{l}}{\pi_{h}}\left(R_{0}+\frac{2}{3} \Omega+\frac{1}{3} \bar{b}\right)-R_{0}\right]+R_{0}}{\lambda \pi_{h}+(1-\lambda) \pi_{l}} \\
R_{A, B}^{1}=\frac{R_{0}-\frac{1}{3} \delta \lambda \bar{b}}{\lambda \pi_{h}+(1-\lambda) \pi_{l}}
\end{gathered}
$$

In the appendix, I show that the assumption of the profits from lending to a bad borrower at optimal interest rates in period 2 being negative in expectation implies that $\begin{gathered}S \\ R_{A}^{1}\end{gathered}>R_{A}^{1}$, , i.e. the first period rates are increasing when switching from a no information sharing to an information sharing regime. This is caused by the fact that under information sharing the insider bank looses the informational advantage on its captured good borrowers. Hence, competition for initial market shares in period 1 is reduced and thus period 1 interest rates increase. Together with decreasing rates for second period loans, higher first period rates imply a more negative difference between first and second period loans, i.e. the interest rate profile of a borrower is more likely to be downward sloping. It is instructive to note that this pre- 
diction on the delta between the first and the second loan is different to the predicted effect of a decrease in moral-hazard. Reducing moral-hazard would have the same effect on a borrower's first and second period interest rates, because for both loans the borrower is less likely to default in the absence of ex-post information asymmetry, which finally leads to the following testable hypotheses for the anti-adverse selection channel of credit information sharing: ${ }^{5}$

Hypothesis 1: The difference between a borrower's second and first loan becomes more negative when information is shared among banks, i.e. the interest rate profile from the first to the second loan is more likely to be downward sloping.

Hypothesis 2: If switching occurs under no information sharing, the gap between rates charged by the insider and the outsider bank is larger under information sharing, i.e. the outsider bank undercuts the insider bank more strongly under information sharing.

From which it follows that:

Hypothesis 3: The share of switchers relative to borrowers who roll over at the insider bank is higher under information sharing.

\section{Methodology}

The credit information sharing system in this study was inaugurated in 2008 at the initiative of the international donor community. All financial institutions covered by the system have to report every single loan they make to the system and are obliged to pull a credit report from the system before

\footnotetext{
${ }^{5}$ The model also predicts that borrowers who default on their first loan will not be granted credit in period 2. As I use data for borrowers that were still active in the market in 2013, my data does not contain a large enough amount of borrowers that defaulted on their first loan. For that reason, I focus my analysis on the effect of credit information sharing on successful borrowers and discard this hypothesis on unsuccessful borrowers.
} 
they grant a new loan. In the early stages of the system, banks started to actively report their borrowers to the system. However, in the beginning, banks were not pulling reports from the system for new to-be-made loans because those reports had to be paid for and did not contain much history or other details about borrowers. Figure 1 shows the usage of the system in the early days. Reporting to the system (the two upper timelines represent records submitted to the system and electronic identification cards for the system issued) picked up much before the actual usage of credit reports for screening purposes (the lower timeline represents reports pulled at the time of a loan application). I use this fact as my main identification strategy and divide the data into a passive information sharing regime before July 2010 and an active information sharing regime thereafter when banks started pulling reports from the system for screening new loans. The regime change is indicated by the horizontal line in Figure $1^{6}$ Importantly, even before information on the system was actively shared and used by banks for screening purposes, I observe the complete set of an individual borrower's loans in the database, even though not all borrowers were recorded in the early days of the system. Identification of borrowers in the system works via biometric electronic cards that are issued by lending banks. A borrower obtaining an electronic identification card at one bank is obliged to use the card for all further loans at other banks. Once a card is issued by the first bank, succeeding banks are likely to use it and report the loan to the information sharing system because they would not have to issue a new card 17

Figure 2 is a graphical representation of my main test of the anti-adverse selection channel of credit information sharing, that I carry out for borrowers that roll over a loan at the insider bank and borrowers that switch to an outsider bank separately 8 The panel structure of the data and the fact that

\footnotetext{
${ }^{6}$ The results of this study are insensitive to moving the cutoff two months back or forth in time.

${ }^{7}$ Non-reported analyses show that for those early borrowers on the system, the data likely captures a full picture of their borrowing because - as is common in this market most borrowers recorded seem to borrow without major interruptions that would indicate missing loans.

${ }^{8}$ This methodology makes the assumption that the banks did not significantly change their lending behavior in anticipation of the regime change. While I cannot rule out that
} 


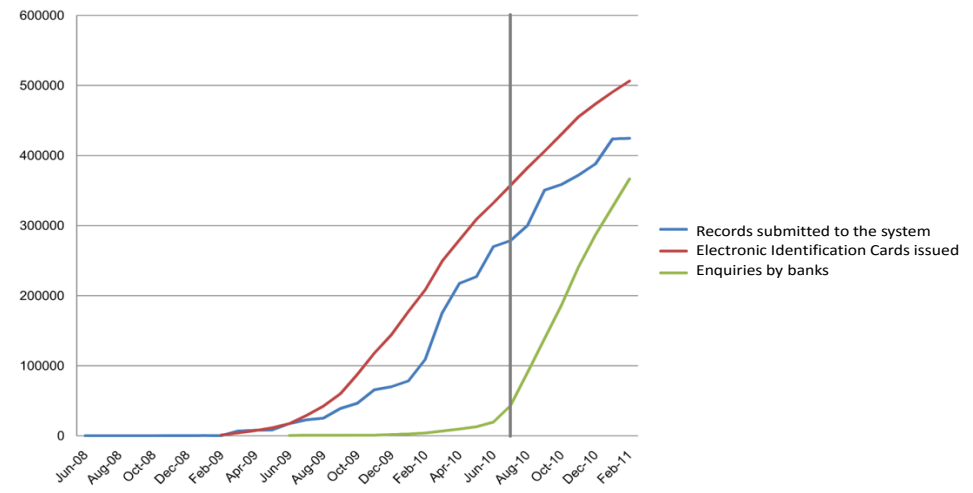

Figure 1

Utilization of the Credit Reference Bureau

most borrowers in the market borrow without much interruption over their economically active lifetime allows me to only consider changes in interest rates from the first to the second loan, instead of comparing levels of interest rates. Theoretically, changes in the interest rate from one loan to another are closely linked to the new information generated over the preceding loan cycle and how the distribution of that information interplays with the new interest rate at the insider or the outsider bank. To test the prediction that the loan profile under active information sharing is more downward sloping, I restrict the sample to borrowers that have obtained both their first and their second loan under a system of no information sharing or information sharing respectively.

Empirically, computing changes of interest rates eliminates bias from time constant borrower level characteristics that are related to the individual interest rate a borrower is able to obtain and that influence both the first and the second loan in the same manner. Comparing rate changes also eliminates some of the bias from time varying borrower level or time varying outside factors that influence interest rates. More specifically, comparing rate changes under the different regimes allows for some trend in the possome banks did, the context suggests that banks did not expect the system to dramatically affect the market before they realized other banks were starting to use the system and moved along triggering a sharp increase in the actual usage. 


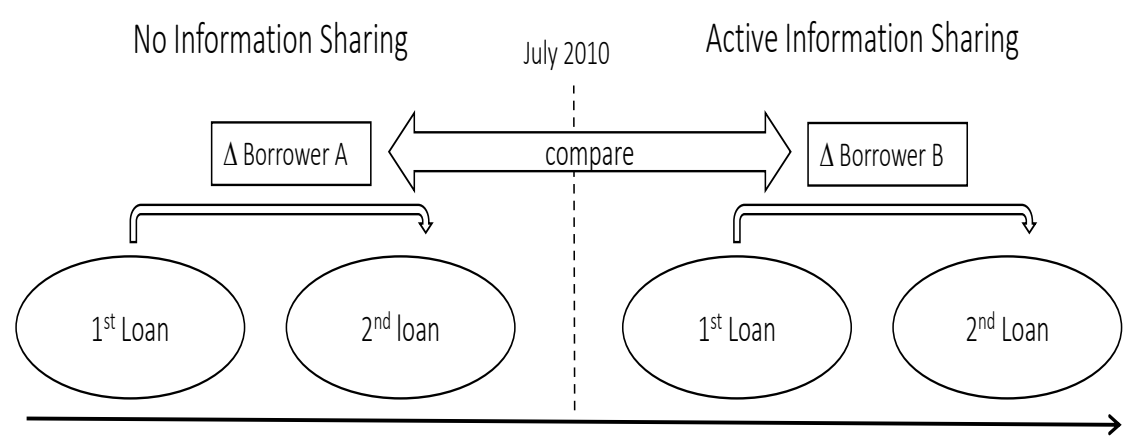

Figure 2

Baseline Methodology

sible confounders. Whenever time varying factors change with the same trend between the first and the second loan under both regimes and do not have non-linear effects on interest rates, the comparison in Figure 2 is an unbiased measure of the effect of information sharing on the interest rate profile $9^{9}$ A mean comparison between interest rates in levels between first loans under both regimes or second loans under both regimes, on the other hand, requires much stronger assumptions. This type of analysis would only be unbiased if time varying factors remained completely constant all the way between the two regimes of information sharing and if in addition all borrower characteristics that matter for the interest rate remained the same between the regimes.

Although, the double differencing approach without further control variables will be unbiased if all factors that affect lending rates feature the same trend over the two loan cycles and do not have non linear effects on the interest rate, I estimate models of the following kind to make sure my results are not driven by factors that affect interest rates and changed their trend between the two regimes:

\footnotetext{
${ }^{9}$ This is similar to a common trend assumption while treatment and no treatment happen at different points in time (i.e. I assume that in the absence of information sharing, the rate change would have to have been the same after the regime change, conditional on control variables).
} 


$$
\Delta \text { Rate }=\alpha+\delta \text { Info-Sharing }+\Delta X \beta+K \theta+\epsilon
$$

Info-Sharing is a dummy equal to one whenever the rate change happened under the effective information sharing system (i.e. after July 2010) and zero otherwise and $\delta$ is the coefficient of interest. $X$ is a matrix of all variables that enter as changes preceding the rate change, i.e. the change over the first loan cycle. This is to capture the same trend assumption and the fact that the difference in interest rates between two loans is not determined by the level of the confounding variable at the time of the uptake of the new loan, but by the change since the last interest rate was set (at the time the first loan was granted). First, to control for volatility on the demand side, I include the change in GDP because an increase in total economic activity suggests a higher demand for loans. Second, to control for monetary conditions and market interest rates, I include the change in the 90-days government bond yield. Third, I control for the change in the average borrower risk in the market using the change in the ratio of non-performing loans to total loans (NPL ratio) in the central bank regulated banking market. Fourth, on the loan supply side, I control for the competition in the banking market using the change in the Herfindahl-Hirschman Index (HHI). Fifth, to control for banking sector liquidity, I include the change in the liquid assets to total assets ratio.

At the borrower level, I control for the change in the share of group loans because group loans (i.e. loans where borrowers have a shared liability for timely repayment of all group members) are still a common practice at the lower end of the banking market in this study and are a driver of average interest rates. The share is either zero or one for borrower with only a single loan outstanding and may take on values in-between if a borrower has multiple outstanding loans. Borrowers who switch from a group loan into an individual loan are likely to receive a lower average interest rate because group loans are on average more expensive. Finally, I also control for the term and the amount of the new loan that is being taken up by the borrower to avoid capturing the effect of follow-up loans that may have 
become larger or more long-term (and thus most likely cheaper) when the information sharing system became effective.

A credit information sharing system may have effects on the pool of first time applicants. While the double differencing approach eliminates most of this compositional bias by using individuals as the reference point, I cannot rule out (or control for the fact) that information sharing affected the overall applicant pool and reduced the average risk of first time applicants, for example because risky borrowers shifted to means of informal finance in the first place when information was shared among banks. It is instructive, however, to note that if indeed information sharing decreases the riskiness of the average first time applicant, this would reduce first loans' interest rates under active information sharing and bias my estimates of information sharing towards zero. That is, if a change in the pool of first applicants' indeed affects first time interest rates negatively, then the true effect of information sharing on adverse selection would be even larger than the one I measure.

\section{Switch vs. Roll Over}

Borrowers who switch banks and borrowers who roll over loans at their current bank may be different with regard to switching costs and individual characteristics. Hence, even if in the baseline analysis of comparing rate changes, the effect of information sharing on switchers was stronger than on borrowers who roll over this would be an insufficient test of the hypothesis 2 which states that outsider banks start bidding more aggressively under information sharing. To control for differences between the two groups and investigate if indeed switchers start to enjoy even more favorable rates under information sharing, I compare borrowers who roll over to borrowers who switch, separately for the two different regimes of information sharing, as shown in Figure 3 . Theory suggests that for similar borrowers the

rate change of switchers relative to borrowers who roll over should be more negative under information sharing than under no information sharing. 


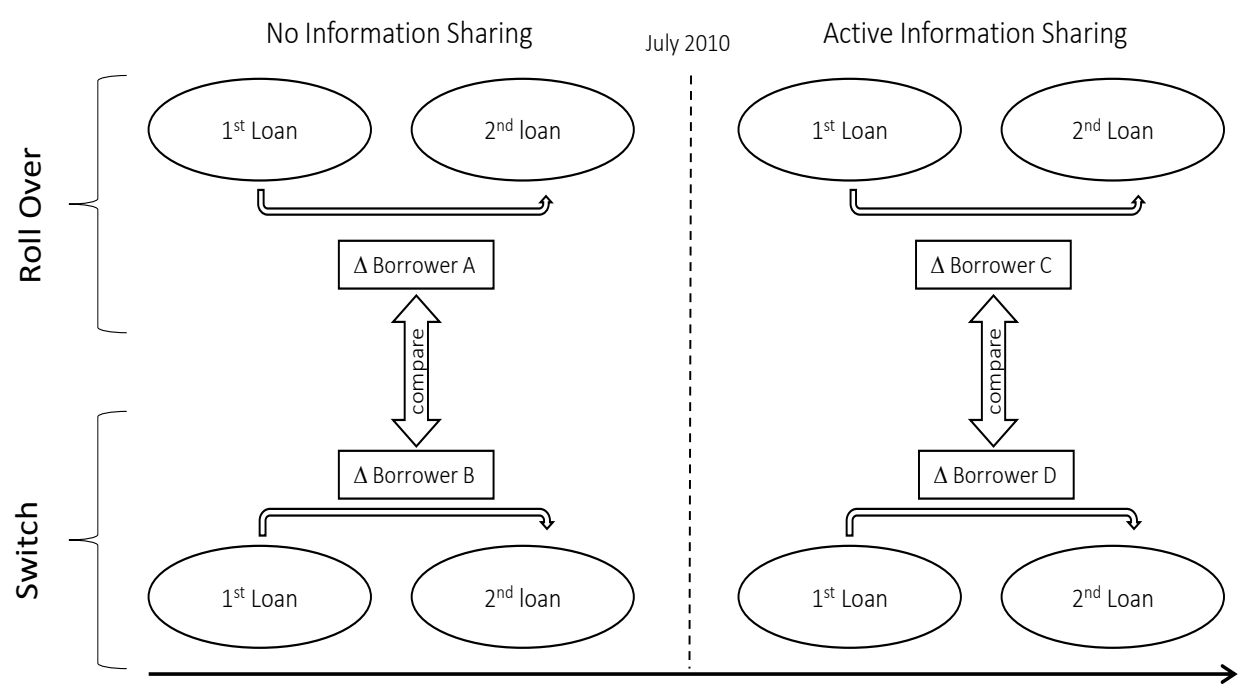

Figure 3

Matching Switchers and Roll Overs

I match switchers and borrowers who roll over using an inverse-probabilityweighted regression-adjustment estimator that separates the matching procedure into one model that is supposed to predict the treatment status (roll over or switch) and another model that is supposed to predict the actual outcome (the interest rate change at the time the second loan was taken up) ${ }^{10}$ This estimator is doubly robust in the sense that it will deliver an unbiased measure of the true difference between the groups if only one of the two models has been specified correctly. The two-step estimator also captures the idea that switching or rolling-over is likely a function of the borrower's current environment while for the interest rate difference between the first and the second loan itself, the change in the control variables since the first loan is decisive.

For the treatment status model, I use levels of available borrower characteristics and macroeconomic variables that may affect the probability of a borrower switching to an outsider bank. I lag the control variables in levels

\footnotetext{
${ }^{10}$ The STATA command teffects ipwra contains additional information on the estimating procedure.
} 
by one month to avoid feedback of the newly obtained loan: the GDP, the 90-days bond yield, the NPL ratio, the HHI, the share of group loans of all the borrower's loans (if there are multiple, otherwise the variable takes on values of zero or one) and the average loan size and loan term of the borrower one month before the uptake of the new loan. Additionally, I include the borrower's age and gender. For the second - the outcome-prediction model, I include the same variables that were part of the baseline regression to predict the interest rate difference at the time a new loan is taken up: The change in GDP since the borrower's first loan was obtained, the change in the bond yield, the change in the NPL ratio, the change in the HHI, the change in the liquid assets to total assets ratio, the change in the share of group loans, the new loan amount and the new loan term.

\section{Data and Summary Statistics}

The data I use for the purpose of this paper entails the complete history of all borrowers who applied at a single bank over the course of the year 2013. This is 62,066 microfinance and SME borrowers at the lower end of the banking market in terms of borrowing volume. The results in this paper therefore pertain to an opaque group of borrowers for which there are usually no detailed tax records or other reliable financial data from outside sources available. For those borrowers, I obtain their full history as recorded on the credit bureau since the beginning of the bureau in late 2008, including loans at other institutions. The data reported to the system contains an unexceptionally detailed record of every single loan a borrower has taken up, including among other things the loan amount, loan term, interest rates, repayment method and the lending institution. The system encompasses all financial institutions that are regulated by the central bank. Although the size of the non-regulated sector is unknown, the system certainly comprises the vast majority of lending in the country.

I search this data for events at which a borrower takes up a new loan at an insider or outsider bank. I define a switcher, i.e. a borrower who obtains a 
loan from an outside bank, to be a borrower who did not have a relationship with the new bank for three months. The three months window is motivated by the short loan cycles that are sometimes as short as six months in this market segment. I exclude events from the analysis where the new loan at the insider or outsider bank is a group loan, but control for the possible effect of this in my analysis. Some loans on the system were recorded retroactively and show up in the very first period. In order to avoid capturing existing loans, I exclude all borrowers that have outstanding loans in the very first period of the system. Excluding borrowers with any delayed loan repayments over the last 12 months, this results in 1,629 observations at which a borrower switches from a loan at one institution into an individual loan at another institution (470 before July 2010 and 1159 for which both the first and the second loan were taken up after July 2010) and 7,862 events at which a borrower rolls over loans at their current institution and as such renegotiate their interest rate (4,273 before July 2010 and 3,588 for which both the first and the second loan were taken up after July 2010). In line with Ioannidou and Ongena (2010), I do not distinguish between borrowers adding a loan at a new institution or actually terminating their old lending relationship, though - if at all - most borrowers keep two loans only for a very short amount of time in my data. All other data on the control variables has been obtained from the Central Bank and the National Bureau of Statistics.

Figure 4 shows all first interest rate changes, i.e. the interest rate on the second loan minus the interest rate on the first loan, of borrowers when they switch to a new bank or roll over an existing loan. The graph only contains observations for which both the first and the second loan were taken up either before or after July 2010. The regime change is indicated by the horizontal line and the downward trend around the regime change is clearly visible. Generally, the interest rate profile turns from upward trending under passive information to downward trending under active information sharing 11

\footnotetext{
${ }^{11}$ The numbers in the graph indicate the number of observations for each month for the combined switcher/roll over timeline. The surge in observations around the regime change
} 


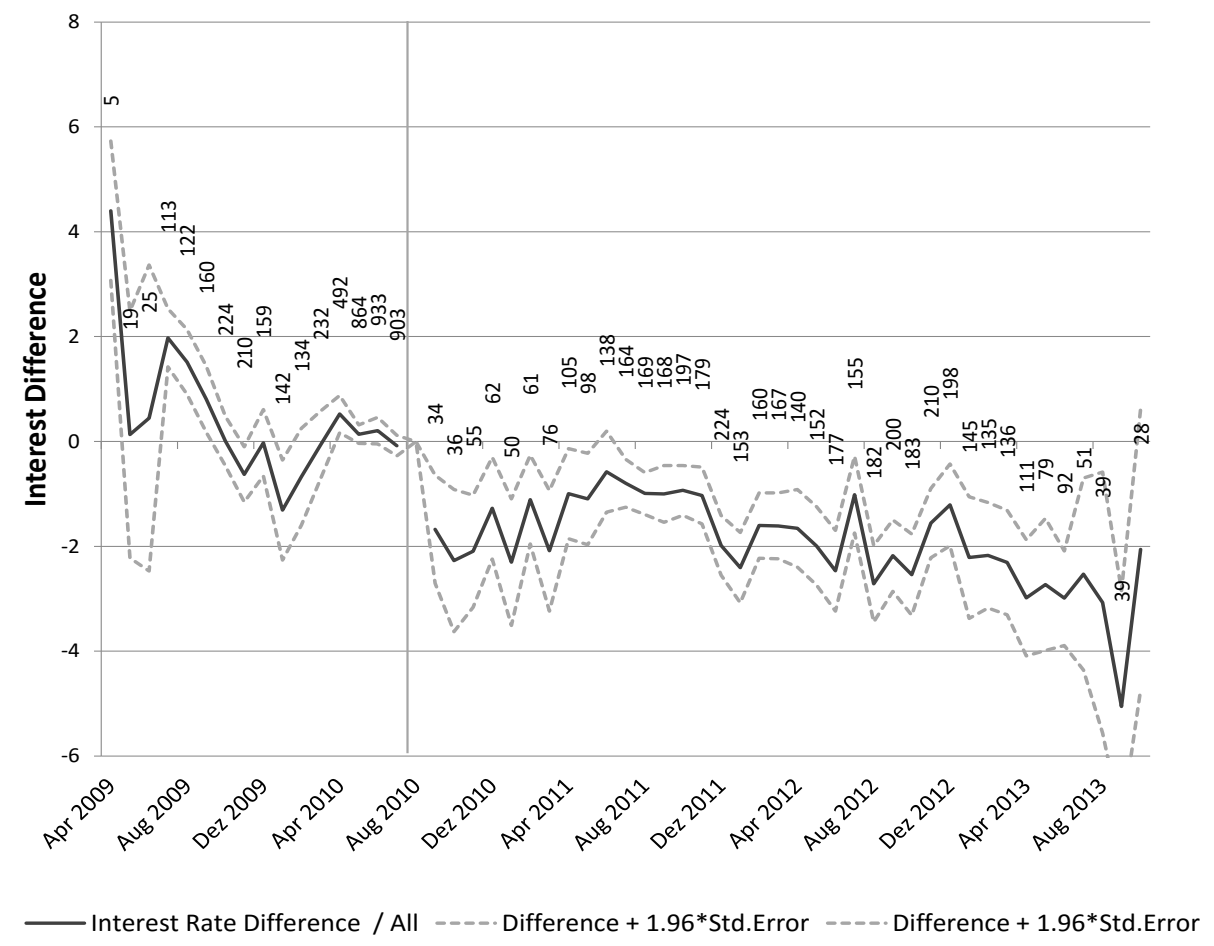

Figure 4

Average Rate Change

Figure 5 breaks the interest rate changes down into borrowers that switch banks and borrowers that roll over loans at their current bank (I omit the confidence intervals and number of observations for easier inspection of the graph). Before July 2010, switchers are faced with a lemon premium at the outsider bank and tend to be forced to switch into much more expensive loans on average (because they may have been credit constrained at their old bank or for example have moved away from a branch of their old bank). And while both borrowers who roll over and switchers start to enjoy cheaper

is mostly driven by the structure of the data because borrowers started to be recorded in bulk about one loan cycle (i.e. six months to a year) before the regime change and then obtained their second loan around the point in time of the regime change. The break in the timeline is due to the fact that no borrower could have taken up a first and a second loan in the month right after the regime change. 


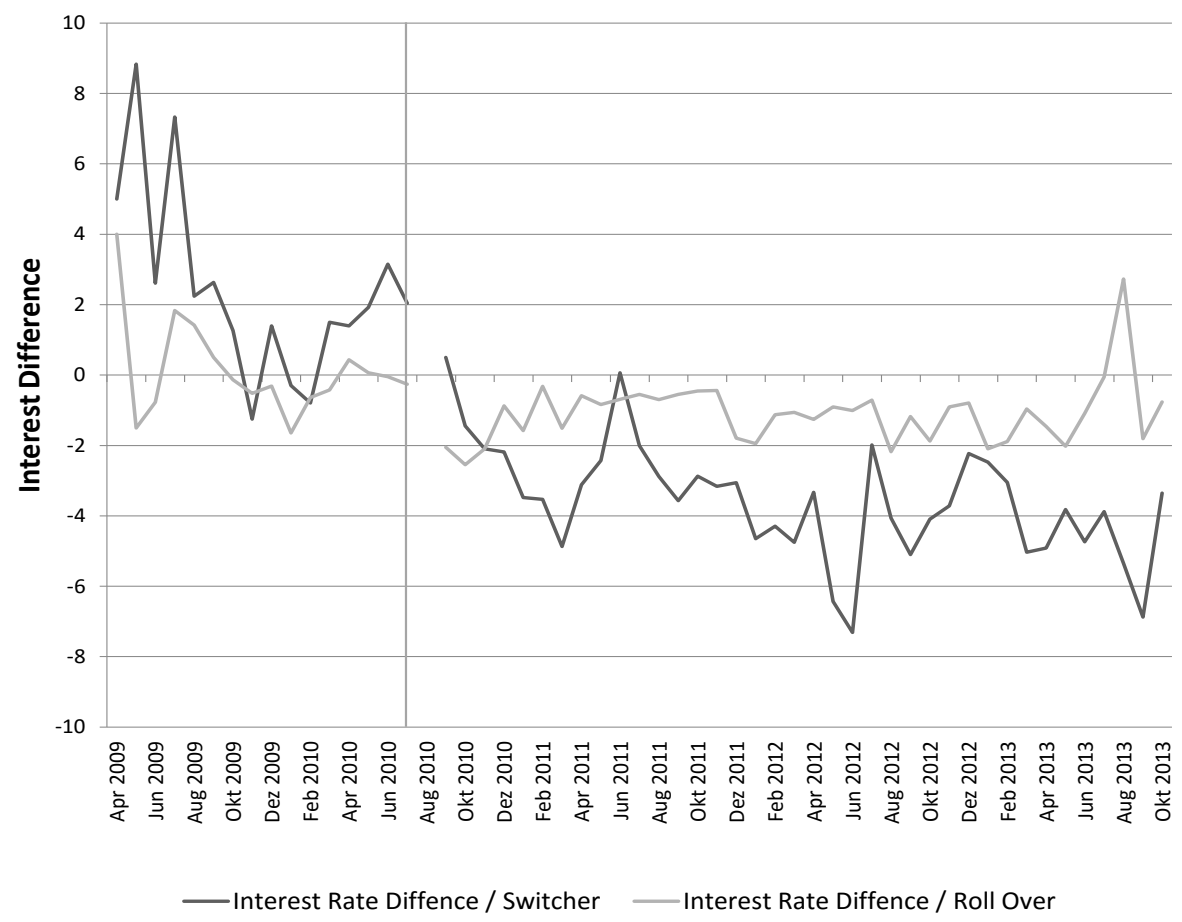

Figure 5

Average Rate Change - Switch vs. Roll Over

rates under information sharing, it is the switchers who profit most from the reduction in asymmetric information in the market as their rate changes turn more favorable than the roll over rate changes under active information sharing 12 Banks in my data do generally not adjust the interest rate over the lifespan of a single loan. In this respect, my data is different to Ioannidou and Ongena (2010) who find a much more dynamic pattern in the rates banks charge their customers. Rate changes in my sample are permanent changes up until the next loan is taken up.

\footnotetext{
${ }^{12}$ Non reported statistics show that switchers or roll overs into a group loan do not profit from a reduction of adverse selection over time. This is to be expected as group-borrowers' interest rates are usually not negotiated freely for a single customer but rather fixed for all members of the group and often also fixed within the group loans product types. This is largely consistent with the findings of Janvry, McIntosh, and Sadoulet (2010).
} 
The following tables contain summary statistics for the control variables without (the left side) and with (the right side) active information sharing. Most variables in changes feature a to some extent different trend before and after the information sharing system became effective, which is why it is important to control for the changes in the macro-level variables. Particularly, the market interest rate measured by the 90-days government bond yield spikes upwards around the same time information starts to be shared actively and normalizes again around one year later (the appendix shows the evolution of the two most volatile macroeconomic control variables, the bond yield and the NPL ratio, graphically). Yet, the shift in the trend of the government bond yield and the NPL ratio is mostly opposite to the trend in interest rate changes with and without active information sharing. Before the system became effective and interest rates were generally upward trending for borrowers, market interest rates were falling and after the system became effective for many borrowers market interest rates were increasing over their first loan cycle. This suggests, that, if bank interest rates reacted at all to the spike in market rates, the true effect of information sharing would be even stronger than the one I measure.

The borrower-level variables also exhibit significant differences between the two different regimes of information sharing. Borrowers in my sample, after information is shared actively, are on average younger and more likely to be male. Loans of switchers become smaller and more short-term after information sharing becomes effective and the loans of borrowers who roll over move the opposite direction. These compositional changes are, however, to be expected as information sharing is likely to affect the pool of borrowers in general and also affects the risk profile of individual that switch banks (Karapetyan and Stacescu 2014). In my regressions, I control for the changes in the average loan term and amount over time (while age and gender are already controlled for by the fact that I use individual interest differences from the first to the second loan on the system). 


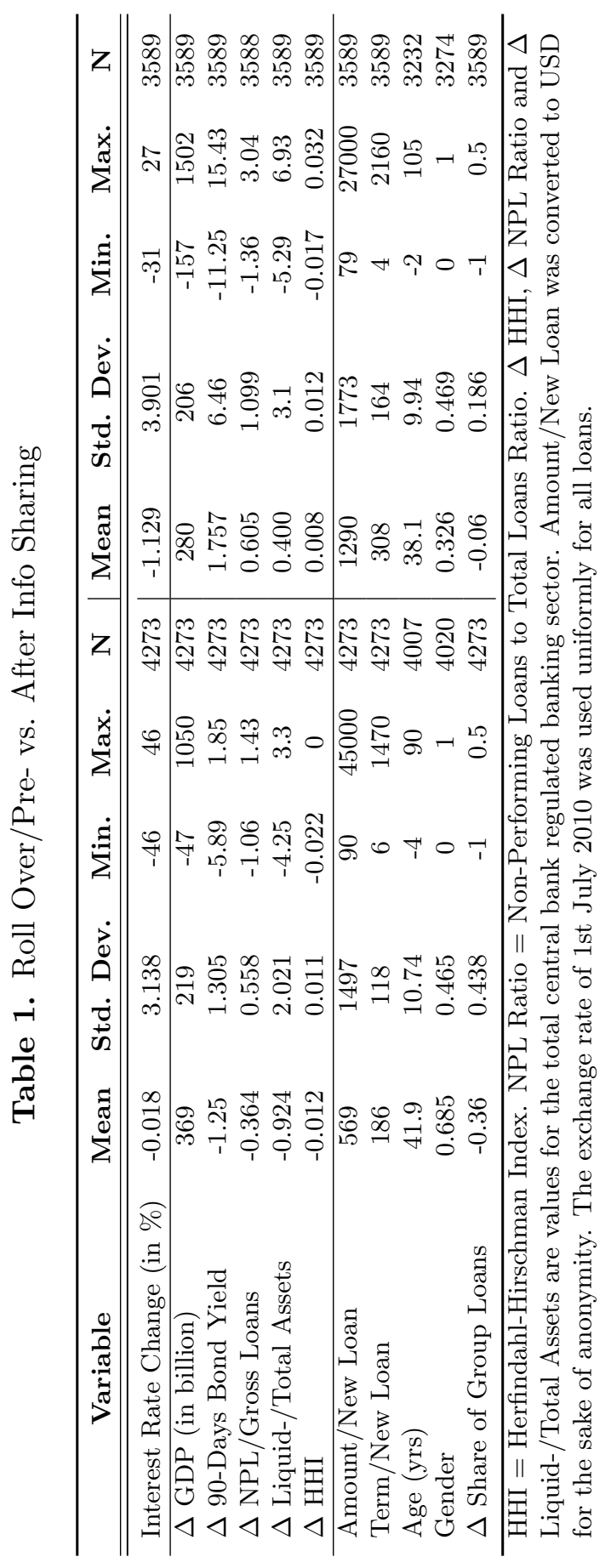




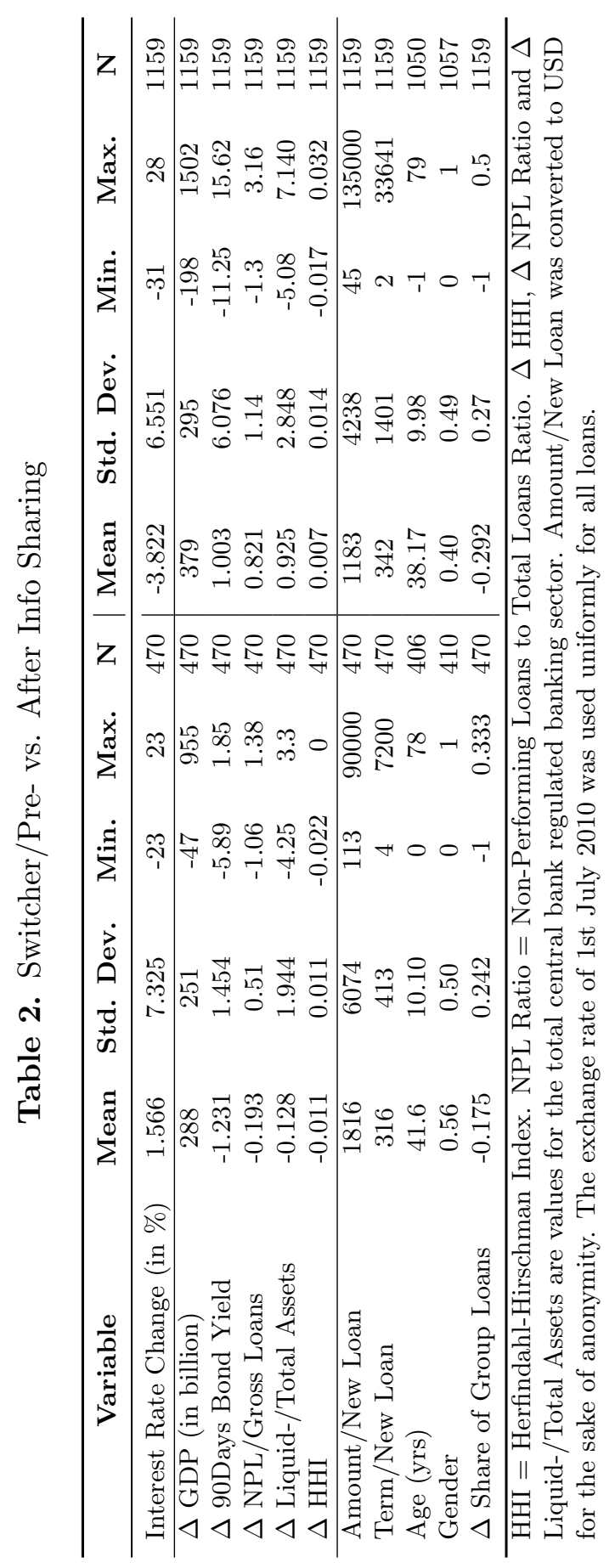




\section{$5 \quad$ Results}

Figure 6 condenses the pattern over time into a double difference estimate of average rate changes between the two regimes for switchers and borrower who roll over. The simple difference in differences estimate suggests that for both borrower groups the interest rate profile turns more downward sloping when credit information is shared actively among banks.

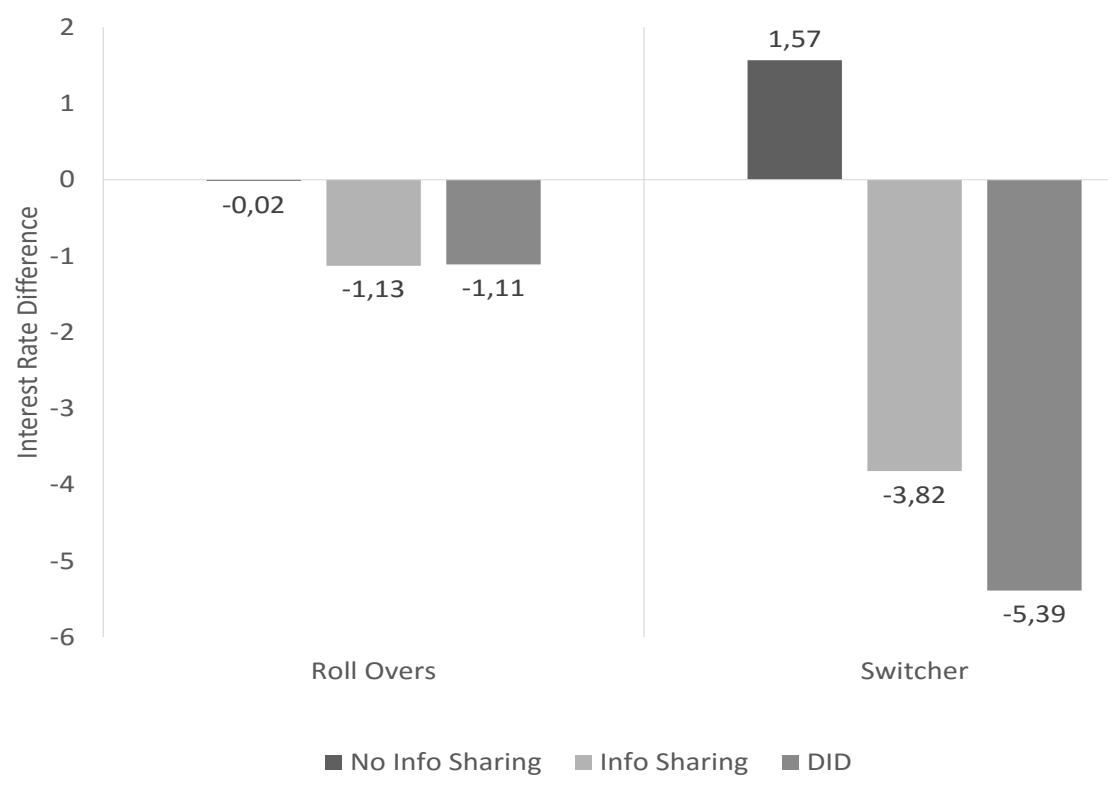

Figure 6

Difference in Differences

Table 3 presents results for the regressions that explicitly control for the possible confounders, distinguishing between switching and rolling over borrowers. For both groups, the effect of information sharing remains highly significant and the economic size of the effect is a lot larger for borrowers who switch to an outsider bank. This is strong support for hypothesis 1: Information sharing has a downward effect on the slope of the interest rate profile of individual borrowers. Relative to the first loans, borrowers' second loans become much cheaper when information is shared actively. Limiting the sample to a window around the regime change, in an attempt to further 
restrict the influence of changes in the environment, does not alter this result, e.g. they remain unchanged for a window of one year. Restricting the sample even further, for example to six months around the regime change, does not change the result for the roll-overs but, due to a limited number of observations, increases standard errors for the switcher-sample rendering the (similiar) effect on switching borrowers statistically insignificant (results are available upon request).

Table 3. Baseline Results

\begin{tabular}{|c|c|c|}
\hline & $\begin{array}{c}\text { Rate Change } \\
\text { Roll Over }\end{array}$ & $\begin{array}{l}\text { Rate Change } \\
\text { Switcher }\end{array}$ \\
\hline Info Sharing & $\begin{array}{c}-0.678^{* * *} \\
(-5.12)\end{array}$ & $\begin{array}{c}-4.132^{* * *} \\
(-8.78)\end{array}$ \\
\hline$\Delta \mathrm{GDP}$ & $\begin{array}{c}-0.000734^{*} \\
(-2.36)\end{array}$ & $\begin{array}{c}0.000790 \\
(1.20)\end{array}$ \\
\hline$\Delta$ 90Days Bond Yield & $\begin{array}{c}-0.0428^{* * *} \\
(-3.35)\end{array}$ & $\begin{array}{c}-0.0787 \\
(-1.56)\end{array}$ \\
\hline$\Delta$ NPL Ratio & $\begin{array}{r}0.0127 \\
(0.12)\end{array}$ & $\begin{array}{c}-0.817^{*} \\
(-2.13)\end{array}$ \\
\hline$\Delta \mathrm{HHI}$ & $\begin{array}{c}-11.98^{*} \\
(-1.98)\end{array}$ & $\begin{array}{l}12.63 \\
(0.63)\end{array}$ \\
\hline$\Delta$ Liquid-/Total Assets & $\begin{array}{c}-0.149^{* * *} \\
(-4.24)\end{array}$ & $\begin{array}{c}0.0106 \\
(0.08)\end{array}$ \\
\hline$\Delta$ Share of Group Loans & $\begin{array}{c}0.162 \\
(1.09)\end{array}$ & $\begin{array}{c}4.977^{* * *} \\
(6.30)\end{array}$ \\
\hline Amount/New Loan & $\begin{array}{c}2.86 \mathrm{e}-08 \\
(1.46)\end{array}$ & $\begin{array}{c}-3.12 \mathrm{e}-08 \\
(-1.59)\end{array}$ \\
\hline Term/New Loan & $\begin{array}{c}-0.000207 \\
(-0.63)\end{array}$ & $\begin{array}{c}-0.000150 \\
(-1.73)\end{array}$ \\
\hline _cons & $\begin{array}{c}0.00935 \\
(0.09)\end{array}$ & $\begin{array}{c}2.204^{* * *} \\
(5.03)\end{array}$ \\
\hline$N$ & 7862 & 1629 \\
\hline \multicolumn{3}{|c|}{$\begin{array}{l}\text { Estimates are the results of an OLS regression. } \Delta \text { HHI, } \Delta \\
\text { NPL Ratio, } \Delta \text { NPL Ratio and } \Delta \text { Liquid-/Total Assets are val- } \\
\text { ues for the total central bank regulated banking sector. HHI } \\
=\text { Herfindahl-Hirschman Index. NPL Ratio = Non-Performing } \\
\text { Loans to Total Loans Ratio. Amount/New Loan was converted } \\
\text { to USD for the sake of anonymity. The exchange rate of } 1 \text { st July } \\
2010 \text { was used uniformly for all loans. } t \text { statistics in parentheses. } \\
{ }^{*} p<0.05,{ }^{* *} p<0.01,{ }^{* * *} p<0.001\end{array}$} \\
\hline
\end{tabular}




\section{Roll Over vs. Switch}

The heterogeneity of the effect of information sharing on switching and rolling over borrowers in the baseline analysis is sizeable, but may also be driven by borrower groups prone to switching that are particularly affected by information sharing. The estimation presented in Table 4 deals with this potential self-selection into switching by matching switching borrowers to borrowers who roll over their loan at the insider bank (the treated borrowers are the ones rolling over their loan). The results are for an inverseprobability-weighted regression-adjustment estimator (the appendix shows the propensity score densities of the two groups, i.e. the overlap). This matching with regression adjustment exercise reduces the raw gap between the insider and outsider rates. The difference between the rate changes, however, remains highly statistically significant. Under a regime of no active information sharing, for both groups the second loan is more expensive than the first. A borrower rolling over a loan pays a hold-up premium and a borrower switching pays a lemon premium at the outside bank. Yet the switcher is worse off: A borrower rolling over at the insider bank faces a $1.71 \%$ points weaker upward jump compared to a similar borrower that switches banks. Curiously, the effect reverses under active information sharing: While both groups manage to obtain a cheaper second loan under active information sharing, a borrower that switches enjoys a $0.94 \%$ points stronger downward jump in the interest rate compared to a similar borrower who rolls over a loan, i.e. the switcher is better off. The findings strongly support hypothesis 2: Under information sharing, adverse selection problem no longer keeps the poaching activities of the outsider in check. The outsider banks start to undercut the insider more fiercely.

The increase in the undercutting activity of the outside bank, implies that more borrowers will switch banks under active information sharing. The following graph shows the share of borrowers who switch banks for their second loan relative to all second loans being taken up (i.e. relative to the sum of borrowers who switch and borrowers who roll over their loans at their cur- 
Table 4. Matching Results / Switch vs. Roll Over

\begin{tabular}{lccccrr}
\hline Variable & Sample & Treated & Controls & Difference & S.E. & T-stat \\
\hline No Information Sharing (Matched Sample & $\mathbf{N = 5 , 6 1 2}$ ) & & \\
\hline$\Delta$ Interest Rate & Unmatched & 0.257 & 3.290 & $-3.033^{* * *}$ & 0.150 & -20.19 \\
& Matched (ATT) & 0.257 & 1.967 & $-1.710^{* * *}$ & 0.524 & -3.26 \\
\hline Information Sharing (Matched Sample N=4,321) & & & \\
\hline$\Delta$ Interest Rate & Unmatched & -1.187 & -4.107 & $2.919^{* * *}$ & 0.162 & 18.00 \\
& Matched (ATT) & -1.187 & -2.122 & $0.935^{* *}$ & 0.328 & 2.85 \\
\hline
\end{tabular}

Results are from a inverse-probability-weighted regression-adjustment estimator. $t$ statistics in parentheses. ATT $=$ Average Treatment effect on the Treated. Treated is the group of borrowers who roll over. ${ }^{*} p<0.05,{ }^{* *} p<0.01$, ${ }^{* * *}$ $p<0.001$

rent bank). The visibly positive trend in the share of events where borrowers switch, indicates that active credit information sharing triggers an increase in the share of switching borrowers. The tails of this graph are somewhat driven by a lower amount of observations and resulting large confidence intervals. However, the average share of switcher that increases from $10 \%$ to $24 \%$ is a clear indication of an increase in the switching activity after credit information is shared actively. To ensure, that this result is not driven by changes in the macroeconomic environment, I regress information sharing (as a dummy variable) on the share of borrowers who switch banks. I control for the same variables as in the previous matching-exercise's treatment model (the GDP, the 90-days bond yield, the NPL ratio, the HHI, the share of group loans of all the borrower's loans and the average loan size and loan term of the borrower, all lagged by one month and also the borrower's age and gender). Results (that are presented in table A1 in the appendix) show that information sharing increased the overall share of switcher by about 20 $\%$ points. Employing fractional logit regression that takes into account the boundedness of the share of switcher variable onto the unit interval does not change this result (results are available upon request), which is strong support for hypothesis 3: When information is shared actively outsider banks 
undercut the insider banks' interest rates more aggressively, which triggers an increase in the switching activity of borrowers.

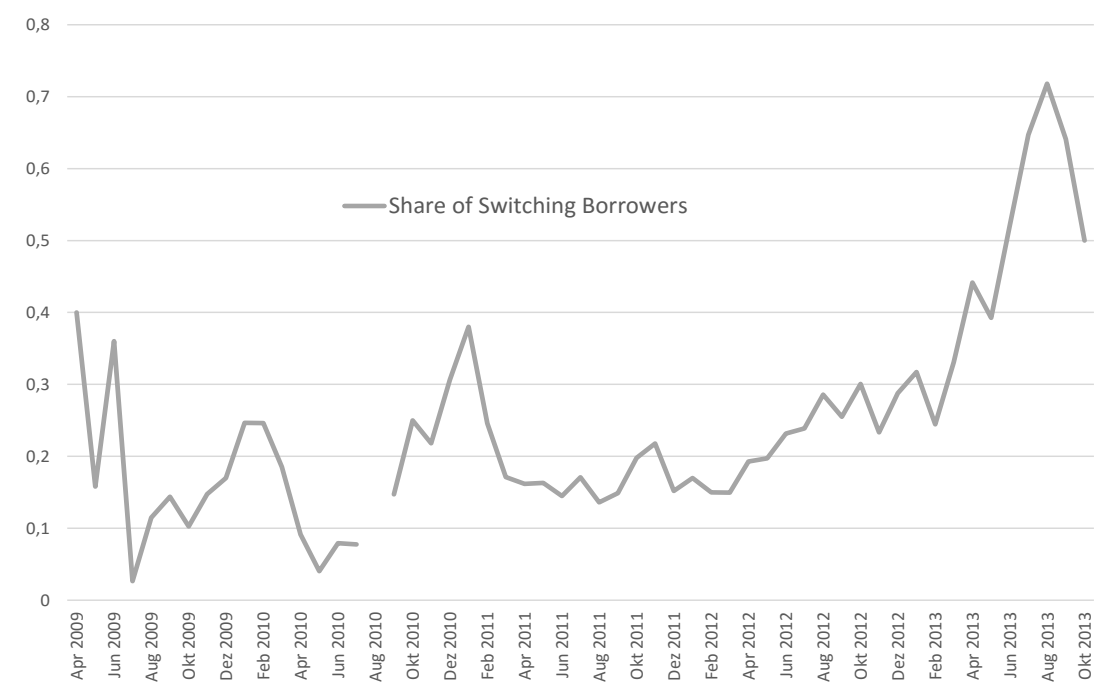

Figure 7

Share of Borrowers that Switch Banks

\section{Robustness Checks}

\section{First vs. Second Loans}

While credit information sharing decreases the costs of a follow-up loan relative to a first loan as predicted by a reduction in adverse selection, it may be instructive to learn about the relative magnitude of the effect on first and second loans seperately. For that matter, I compare the interest rates for first-time borrowers and for follow-up loans between both regimes of information sharing separately, as depicted in Figure 8. This analysis in levels, however, is more prone to the fact that the information sharing system may have compositional effects and change the average characteristics of borrowers that take up loans. While my main methodology controls for most of these changes by double differencing time-fixed individual effects away, I now need to control for all factors that affect interest rates and have 
changed over the course of time between the two regimes of information sharing. To do so, I match first-time borrowers that took up their first loan before July 2010 with first-time borrowers that took up their first loan after July 2010 on macroeconomic measures in levels (GDP, the bond yield, the NPL ratio, the HHI, the liquid assets to total assets ratio in the banking sector) and on the borrower's age and gender, the loan amount and the loan term at the time the borrower obtained the first loan. I repeat the same exercise for borrowers' second loans.

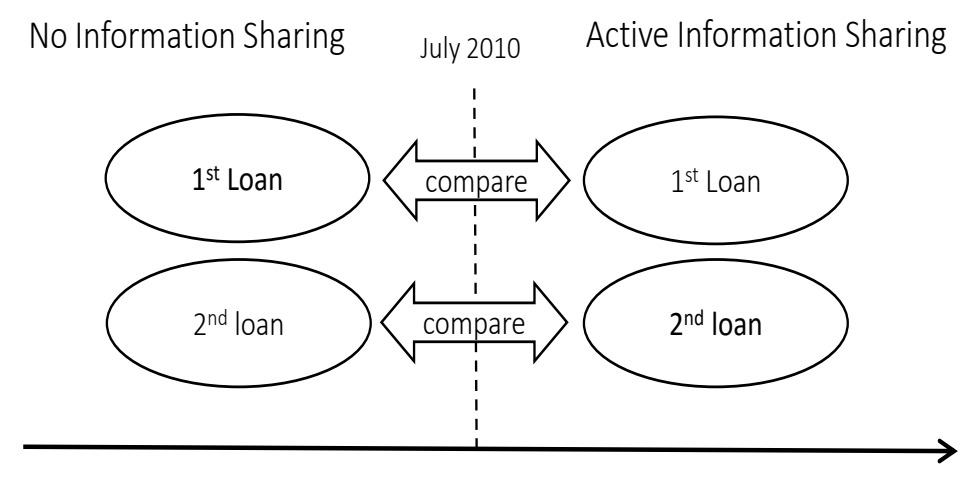

Figure 8

Matching First and Second Loans

Loans under information sharing are the treated group and I employ propensity score matching using nearest neighbor matching with a caliper and without replacement to avoid very dissimilar matches. The appendix shows the propensity score densities of the two groups, i.e. the overlap (balancing-score properties are available upon request) ${ }^{13}$

In both cases, matching the two groups, and amply discarding observations outside the overlap region, reduces the gap in the mean, but the difference

\footnotetext{
${ }^{13}$ Two macroeconomic variables, the GDP level and the level of the 90-days government bond yield are problematic. The GDP level is highly explanatory in the propensity score estimation as it rises steadily over the time period of my sample and thus predicts active or passive information sharing. The bond yield in levels is highly correlated to the ratio of liquid assets to total assets. The estimations presented here therefore discard both variables. I find it unlikely, however, that the level of GPD is a strong upward driver of first period interest rates and downward driver of second period interest rates the same time.
} 
between the matched active information sharing and passive information sharing sample remains highly statistically significant. Information sharing reduces rates for follow-up loans of repeated borrowers and increases interest rates for first-time borrowers and the change in the interest rate profile in my analysis is the the combined effect of both. The economic size of the effects is meaningful. The $1.69 \%$ points increase in first period interest rate for the treated borrowers constitutes about a $4 \%$ increase of the average interest rate. The $3.86 \%$ points reduction in second period loans under information sharing, on the other hand, means the average interest rate paid by borrowers decreases by almost $11 \%$. The increase in competition for successful repeated borrowers incentivizes banks to compete less fiercely for new borrowers. The interest rate reducing effect on second period loans, however, surpasses the interest rate increasing effect on first loans by a sizeable margin.

Table 5. Matching Results / First and Second Time Borrowers

\begin{tabular}{lrrrrrr}
\hline Variable & Sample & Treated & Controls & Difference & S.E. & T-stat \\
\hline Interest Rate & Unmatched & 41.34 & 39.80 & $1.54^{* * *}$ & 0.10 & 15.46 \\
(First Loan) & Matched (ATT) & 40.77 & 39.08 & $1.69^{* * *}$ & 0.18 & 9.34 \\
\hline Interest Rate & Unmatched & 33.37 & 39.70 & $-6.33^{* * *}$ & 0.16 & -39.03 \\
(Second Loan) & Matched (ATT) & 34.54 & 38.40 & $-3.86^{* * *}$ & 0.37 & -10.51 \\
\hline
\end{tabular}

Results are from a propensity score matching using nearest neighbor matching with a caliper and without replacement. ATT $=$ Average Treatment effect on the Treated. Treated is the group of borrowers obtaining their loan under active information sharing. ${ }^{*} p<0.05,{ }^{* *} p<0.01,{ }^{* * *} p<0.001$

\section{Other Outcome Variables}

A loan's interest rate is just one of many features of a loan contract. While I control for the effect of the loan term and the loan volume on the change in interest rate, it may be instructive to check whether, besides the interest rate, the other loan features changed after information started to be shared actively as well. In the appendix, I show the evolution of the changes in loan terms (in months) and changes in the loan volumes between first and second loans, separately for switchers and borrowers who roll over. A visible 
inspection of figures A6, A7, A8 and A9 suggest that it was in particular the interest rate that reacted to active information sharing.

To control for possible confounders, table A2 in the appendix presents results employing the same baseline methodology as for the interest rate change before, but using the loan term and volume changes as outcome variables controlling for the respective other two loan features. Results show that there is mostly no significant effect of information sharing on the other loan features. This is, however, highly plausible given the fact that the most visible lever for banks to market to borrowers is the interest rate, and not the loan volume or the loan term. A cheaper loan at another bank is the prime reason to switch or stay.

\section{Conclusion}

The introduction of a credit information sharing system that banks use to share information about existing borrowers with outsider banks strongly affects the distribution of information in credit markets and market outcomes as such. Here, I study the effect of information sharing among banks on the interest rates borrowers pay for their loans. I base my identification strategy on a special feature of the introduction of a credit information sharing system that was not actively used in its beginnings for borrower screening, yet recorded borrowers right from the start. As a result, this paper is the first to establish a clean no-information-sharing control group but also to track borrowers through the banking system to control for compositional changes in banks' portfolios.

The results lend strong support to the idea that information sharing acts as an efficient device to mitigate adverse selection problems and informational hold-up by insider banks. Without active information sharing, successful borrowers are unable to demonstrate their creditworthiness, i.e. they face a lemon premium at outsider banks because of being pooled with less creditworthy borrowers. The insider bank uses this informational edge to its advantage and is able to charge higher rates to its successful borrowers it- 
self. Indeed, I find in my data that when no information is shared follow-up loans are on average more expensive than borrowers' first loans (an upward sloping interest rate profile). On the other hand, when banks start to use the shared information actively for screening purposes, borrowers that have successfully repaid their first loan start to enjoy cheaper follow-up loans as their first bank is unable to hold them back (the interest rate profile turns downward sloping). Switchers profit most from the reduction in adverse selection problems due to information sharing. After matching switching borrowers and borrowers who roll over their loan at the current institution, I find that the downward movement of a follow-up loan is much stronger for switchers. This is because information sharing makes outsider banks compete more fiercely for successful borrowers, as the outsiders' poaching activities are no longer held in check by the adverse selection they face when no borrower information is shared.

The downturn in the interest rate profile of borrowers is, however, not only a result of decreasing rates for follow-up loans under information sharing. The gain in competition for repeated successful borrowers does also come with some costs attached. New borrowers in the market, i.e. borrowers without any borrowing history, start to pay higher interest rates once the information sharing system becomes effective. This is because the informational rents that banks are able to extract from their existing borrowers are lower under information sharing which renders reaching out to new borrowers less attractive in the first place. This eventually reduces competition for initial market shares. However, I find that the interest rate reducing effect of mitigating adverse selection for follow-up loans is much stronger than the anti-competition effect information sharing has on initial loans. This difference hints at an overall increase in credit market efficiency when the information playing field among banks becomes more leveled. Cheaper follow-up loans that successful borrowers are able to obtain when information is shared constitute a reward for timely repayment and facilitate more efficient bank borrower matches. On top of that information sharing likely mitigates moral hazard concerns, which further speaks for the overall desirability of credit information sharing among banks. 


\section{Appendix}

\section{Period 1 Interest Rates Comparison - Proof}

I compare the following interest rates in period 1 under information sharing and no information sharing:

$$
\begin{gathered}
\frac{R_{0}-\frac{1}{3} \delta \lambda \bar{b}}{\lambda \pi_{h}+(1-\lambda) \pi_{l}}>\frac{-\delta \lambda \frac{1}{3}\left(\Omega+\bar{b}+\frac{\Omega^{2}}{\bar{b}}\right)+\delta(1-\lambda)\left[\frac{\pi_{l}}{\pi_{h}}\left(R_{0}+\frac{2}{3} \Omega+\frac{1}{3} \bar{b}\right)-R_{0}\right]+R_{0}}{\lambda \pi_{h}+(1-\lambda) \pi_{l}} \\
\Leftrightarrow 0>-\delta \lambda \frac{1}{3}\left(\Omega+\frac{\Omega^{2}}{\bar{b}}\right)+\delta(1-\lambda)\left(\frac{\pi_{l}}{\pi_{h}}\left(R_{0}+\frac{2}{3} \Omega+\frac{1}{3} \bar{b}\right)-R_{0}\right) \\
\Leftrightarrow 0>-\frac{-\lambda \pi_{h}}{(1-\lambda) \pi_{l}} * \frac{1}{3}\left(\Omega+\frac{\Omega^{2}}{\bar{b}}\right)+R_{0}+\frac{2}{3} \Omega+\frac{1}{3} \bar{b}-\frac{\pi_{h}}{\pi_{l}} R_{0}
\end{gathered}
$$

Since:

$$
\frac{\bar{b}(1-\lambda) \pi_{l}}{\lambda \pi_{h}}=\Omega
$$

$$
\begin{gathered}
\Leftrightarrow 0>-\frac{1}{3} \bar{b}-\frac{1}{3} \Omega+R_{0}+\frac{2}{3} \Omega+\frac{1}{3} \bar{b}-\frac{\pi_{h}}{\pi_{l}} R_{0} \\
\Leftrightarrow 0>\frac{1}{3} \Omega-\frac{\pi_{h}}{\pi_{l}} R_{0}
\end{gathered}
$$

To show that this actually holds, I use the assumption that the profits from lending to a bad borrower in expectations are - given optimal interest rates in period 2 - negative:

$$
\pi_{l} R_{A}^{2}-R_{0}<0
$$


Using the optimal interest rate $\stackrel{N S}{R_{A}^{2}}$ in period 2 under no information sharing (the fact that the rate under sharing is lower than under no sharing implies that this condition will also hold for the rate under sharing), I find that:

$$
\begin{aligned}
& \pi_{l}\left(\frac{3 R_{0}+\Omega+2 \bar{b}}{3 \pi_{h}}\right)-R_{0}<0 \\
& \Leftrightarrow R_{0}+\frac{1}{3} \Omega+\frac{2}{3} \bar{b}-\frac{\pi_{h}}{\pi_{l}} R_{0}<0
\end{aligned}
$$

From here it is obvious that since this holds by assumption then (1) must also hold which means that $\begin{aligned} S & R_{A}^{1}\end{aligned} \stackrel{N}{S}_{A}^{1}$, i.e. the first period rates are increasing when we move from a no information sharing to an information sharing regime. 


\section{Macroeconomic Control Variables}

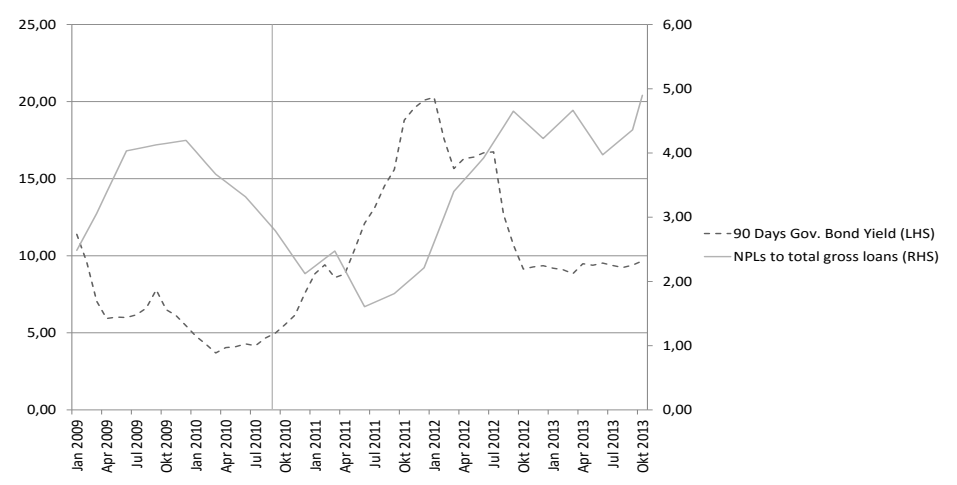

Figure A1

Macroeconomic Control Variables / Trend 


\section{Matching Roll Over vs. Switch}

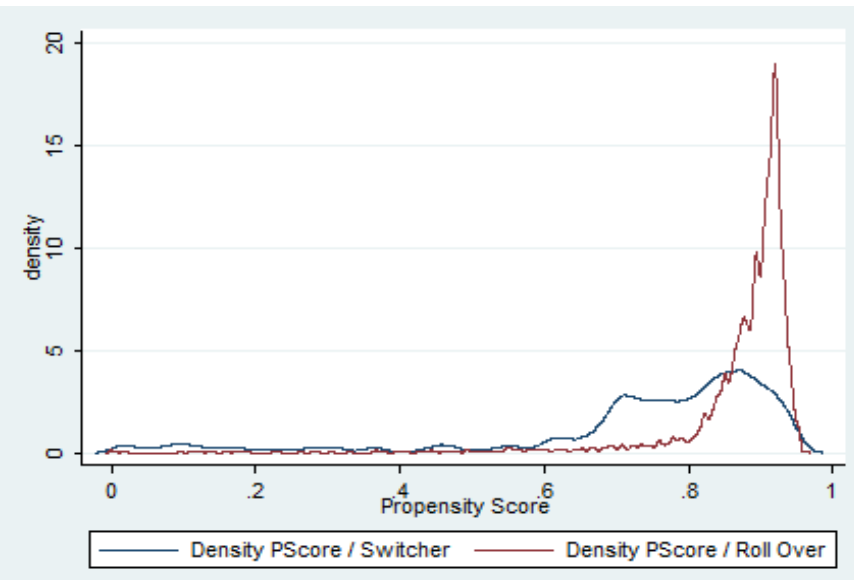

Figure A2

Common Support / Switch and Roll Over / No Info Sharing

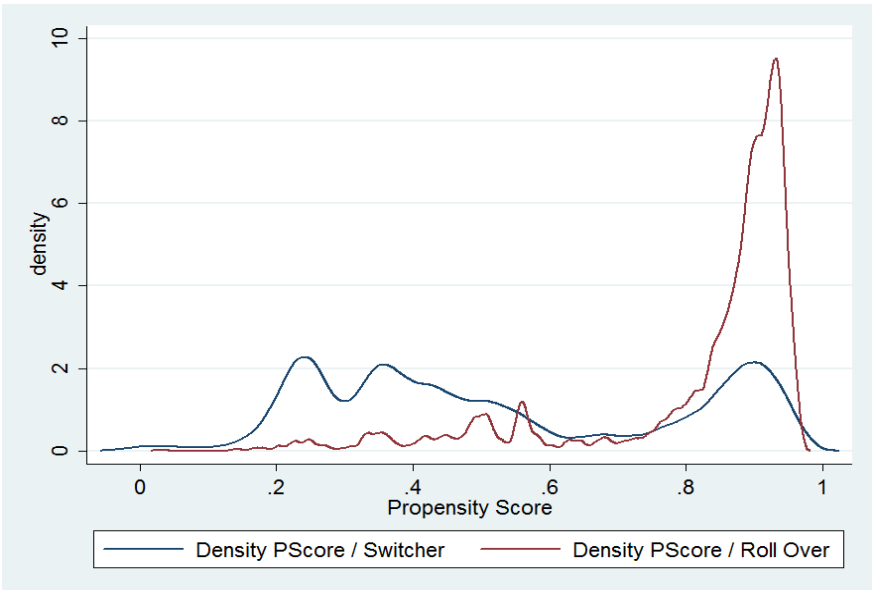

Figure A3

Common Support / Switch and Roll Over / Info Sharing 
Table A1. Share of Switchers (Hypothesis 3)

\begin{tabular}{|c|c|}
\hline & Share of Switchers \\
\hline Info Sharing & $\begin{array}{c}0.193^{* * *} \\
(27.81)\end{array}$ \\
\hline GDP (t-1) & $\begin{array}{c}0.0000213^{* * *} \\
(4.73)\end{array}$ \\
\hline 90Days Bond Yield t-1) & $\begin{array}{c}-0.00177^{* * *} \\
(-5.03)\end{array}$ \\
\hline NPL/Gross Loans (t-1) & $\begin{array}{c}0.0757^{* * *} \\
(23.23)\end{array}$ \\
\hline HHI (t-1) & $\begin{array}{c}-2.204^{* * *} \\
(-12.73)\end{array}$ \\
\hline Liquid-/Total Assets (t-1) & $\begin{array}{c}-0.00103 \\
(-1.07)\end{array}$ \\
\hline Share of Group Loans (t-1) & $\begin{array}{c}-0.0157^{* * *} \\
(-9.12)\end{array}$ \\
\hline Average Individual Loansize (t-1) & $\begin{array}{c}1.16 \mathrm{e}-09^{*} \\
(2.28)\end{array}$ \\
\hline Average Individual Loan Term (t-1) & $\begin{array}{r}-4.4 \mathrm{e}-7 \\
(-0.19)\end{array}$ \\
\hline Age & $\begin{array}{c}-0.000143^{*} \\
(-2.05)\end{array}$ \\
\hline Gender & $\begin{array}{c}0.00211 \\
(1.36)\end{array}$ \\
\hline _cons & $\begin{array}{l}0.176 \\
(1.80)\end{array}$ \\
\hline$N$ & 8687 \\
\hline \multicolumn{2}{|c|}{$\begin{array}{l}\text { Estimates are the results of an OLS regression. HHI, NPL Ra- } \\
\text { tio, NPL Ratio and Liquid-/Total Assets are values for the to- } \\
\text { tal central bank regulated banking sector. HHI = Herfindahl- } \\
\text { Hirschman Index. NPL Ratio = Non-Performing Loans to Total } \\
\text { Loans Ratio. Amount/New Loan was converted to USD for the } \\
\text { sake of anonymity. The exchange rate of } 1 \text { st July } 2010 \text { was used } \\
\text { uniformly for all loans. } t \text { statistics in parentheses. }{ }^{*} p<0.05 \text {, } \\
{ }^{* *} p<0.01,{ }^{* * *} p<0.001\end{array}$} \\
\hline
\end{tabular}




\section{Matching First and Second Time Borrowers}

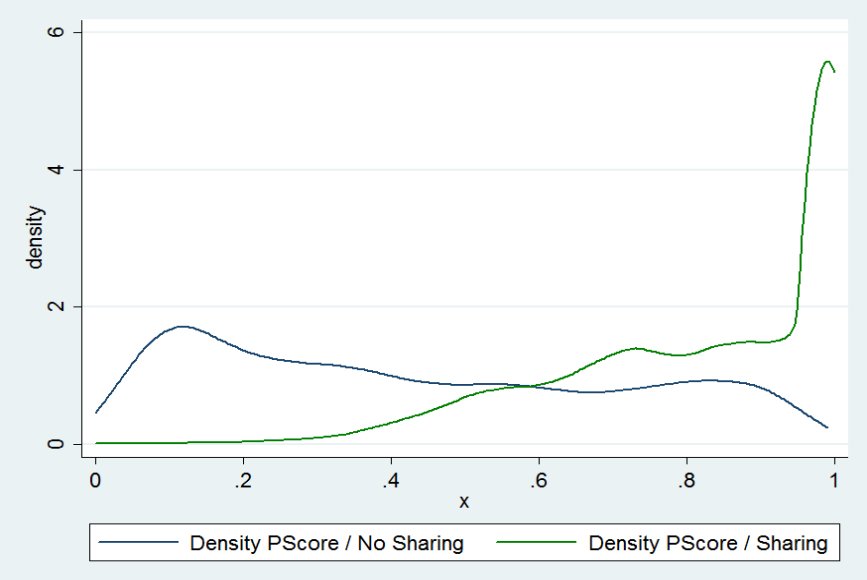

Figure A4

Common Support / First-time Borrowers

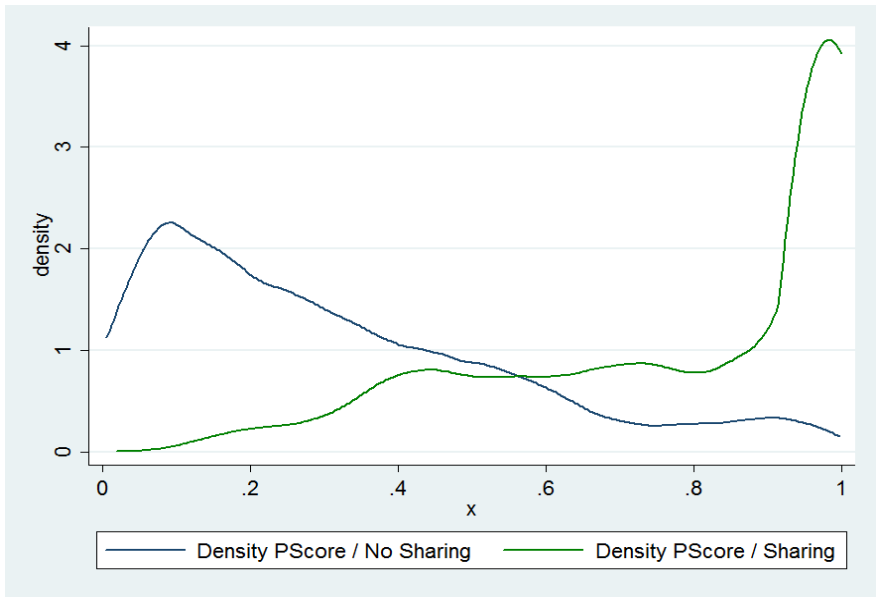

Figure A5

Common Support / Second Time Borrowers 


\section{Other Loan Terms}

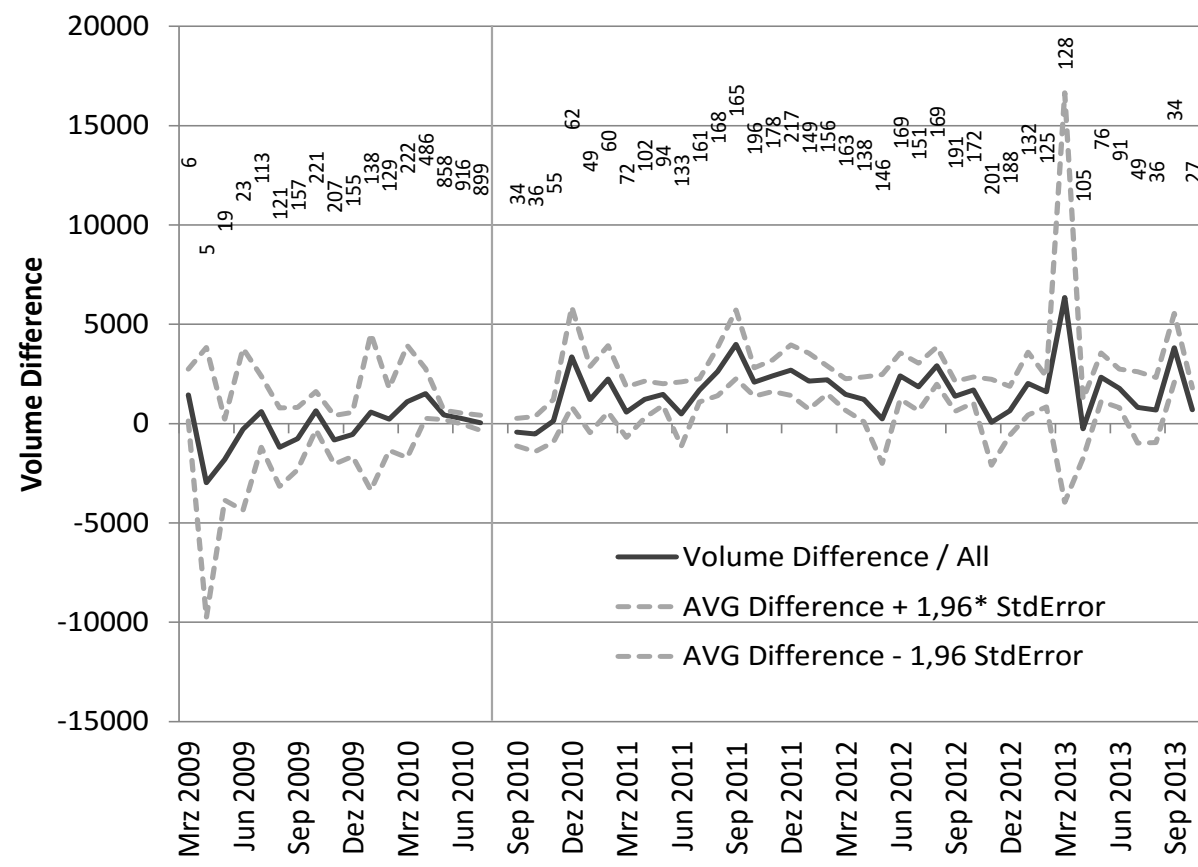

Figure A6

Average Volume Change 


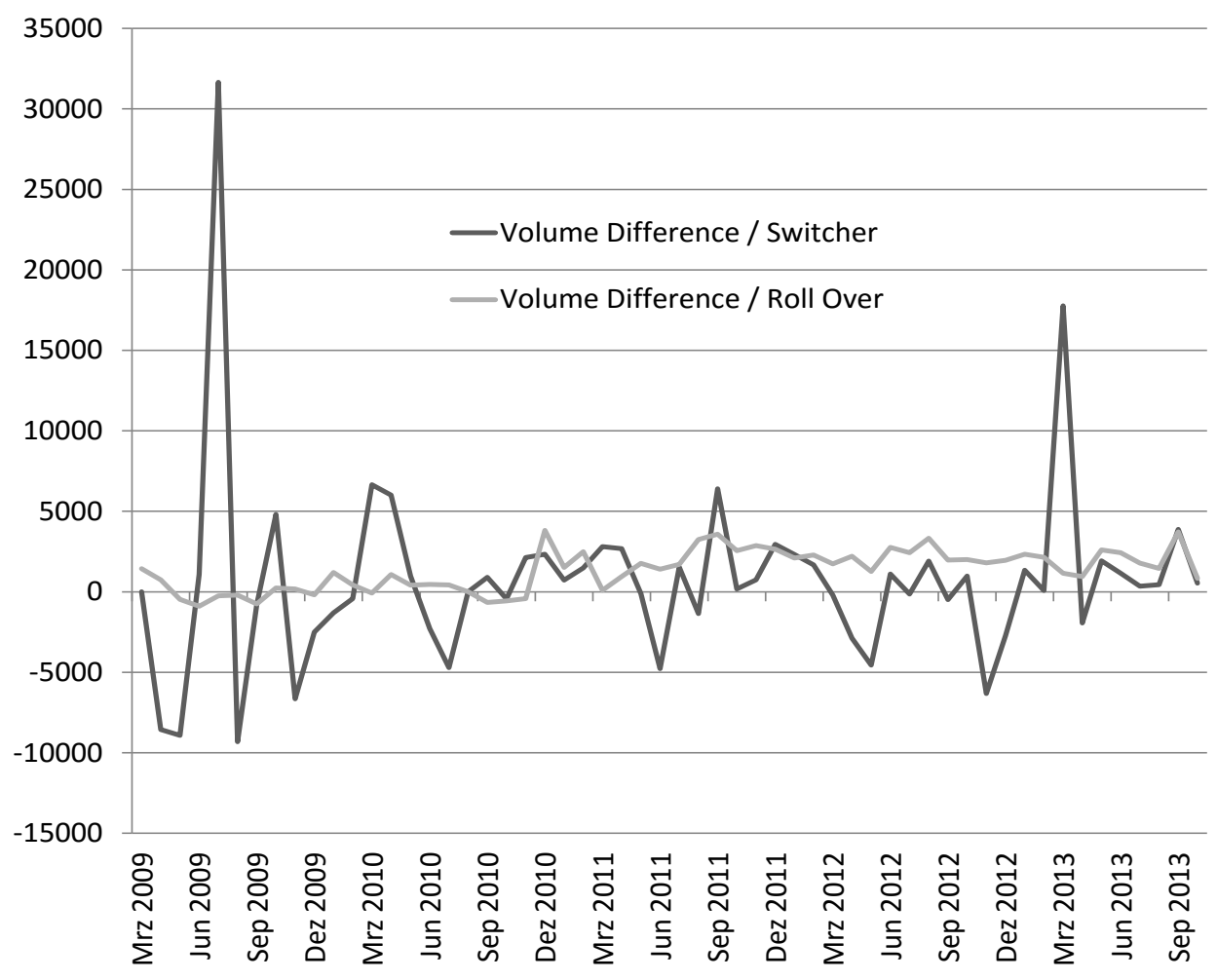

Figure A7

Average Volume Change - Switch vs. Roll Over 


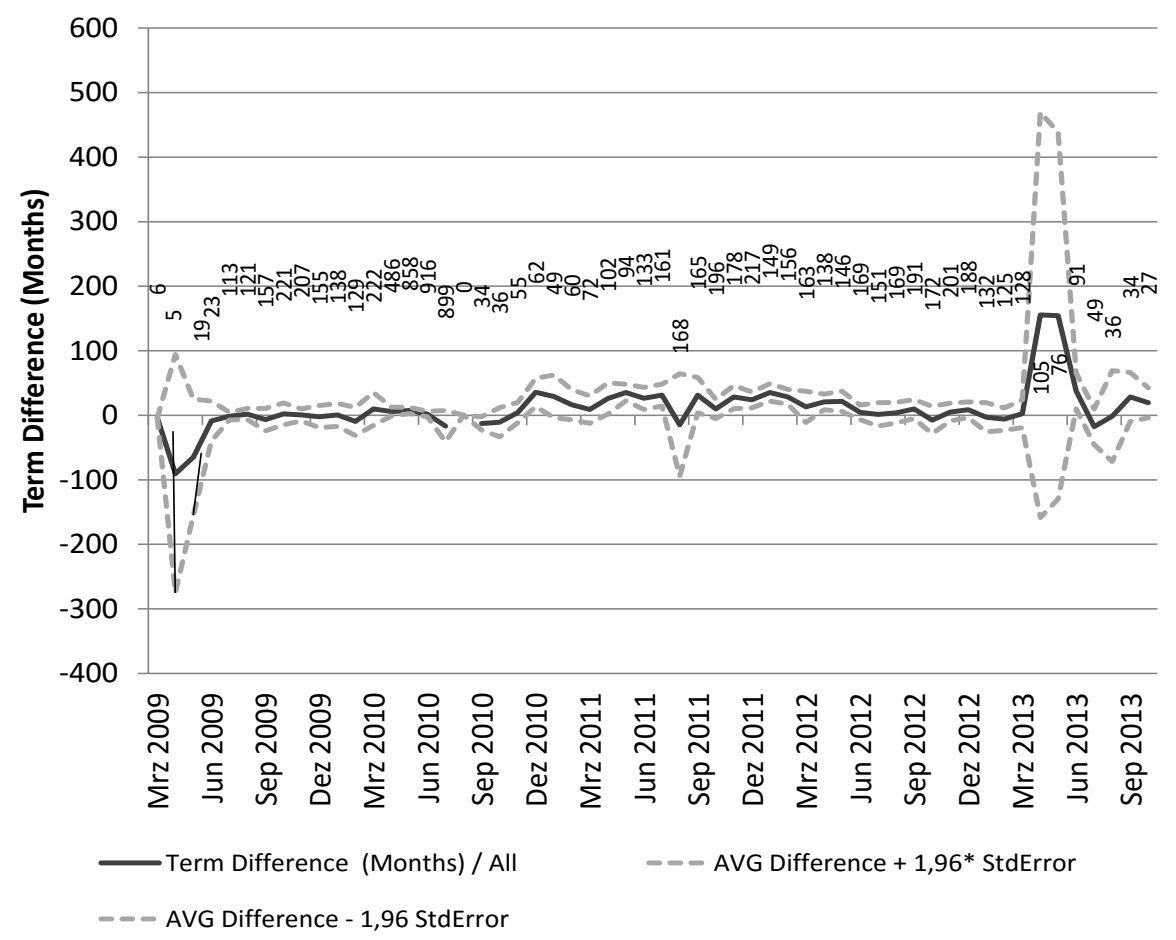

Figure A8

Average Term Change 


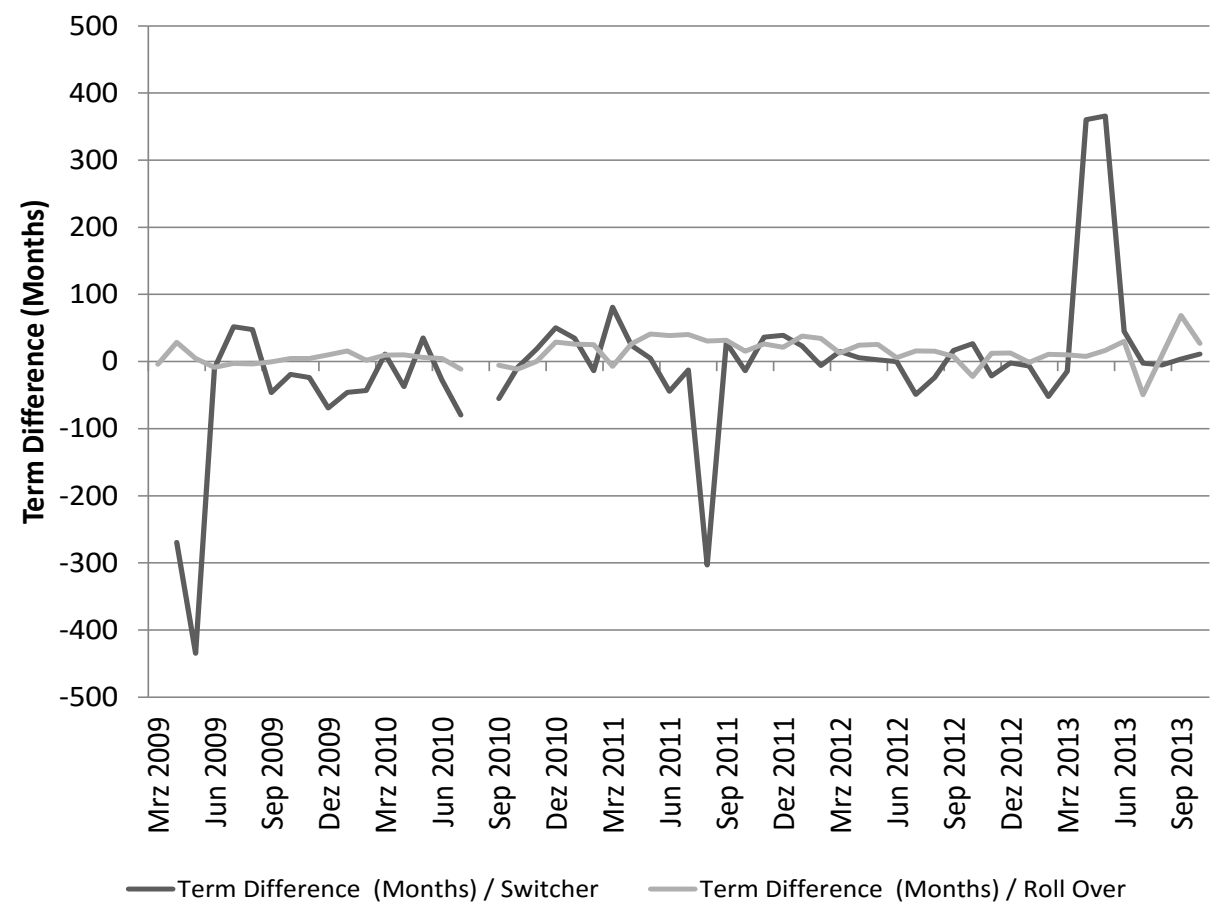

Figure A9

Average Term Change - Switch vs. Roll Over 


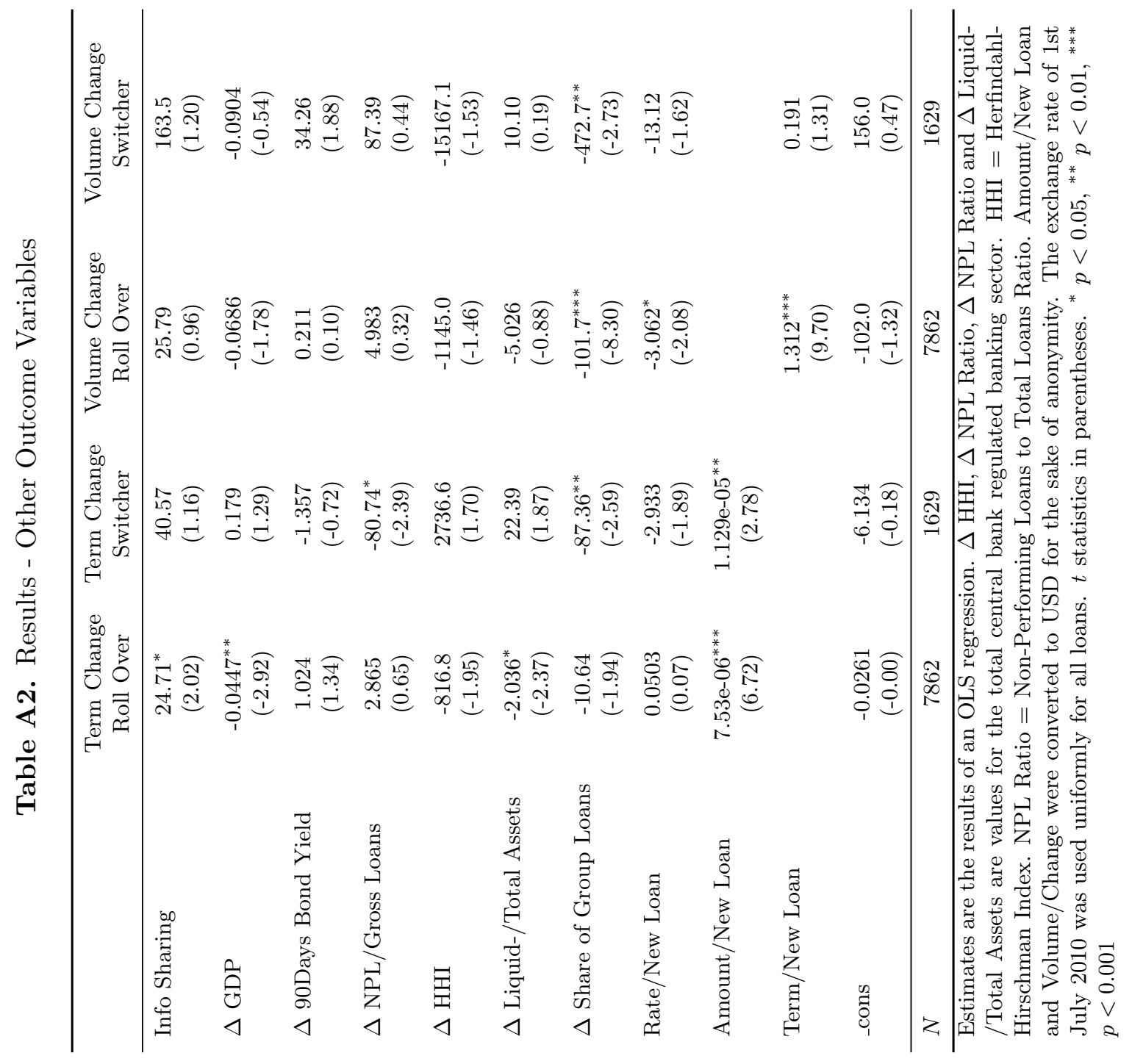




\section{References}

Behr, Patrick and Simon Sonnekalb (2012). "The effect of information sharing between lenders on access to credit, cost of credit, and loan performance Evidence from a credit registry introduction". In: Journal of Banking 8 Finance 36(11). International Corporate Finance Governance Conference, pp. 3017 -3032. ISSN: 0378-4266. DOI: http://dx.doi.org/ 10.1016/j.jbankfin.2012.07.007.

Bennardo, Alberto, Marco Pagano, and Salvatore Piccolo (2014). "Multiple Bank Lending, Creditor Rights, and Information Sharing". In: Review of Finance. DOI: 10 .1093/rof/rfu001. eprint: http://rof . oxfordjournals . org/ content / early/2014/02/18/rof . rfu001. full.pdf+html.

Bos, Jaap W.B., Ralph de Haas, and Matteo Millone (2015). "Show Me Yours and I'll Show You Mine: Sharing Borrower Information in a Competitive Credit Market". In: CentER Discussion Paper Series No. 2015027 No. 2015-027. DOI: http://dx.doi.org/10.2139/ssrn.2599993.

Bouckaert, Jan and Hans Degryse (2004). "Softening Competition by Inducing Switching in Credit Markets". In: The Journal of Industrial Economics 52(1), pp. 27-52. ISSN: 1467-6451. DOI: 10.1111/j.0022-1821. 2004.00215.x.

Brown, Martin, Tullio Jappelli, and Marco Pagano (2009). "Information sharing and credit: Firm-level evidence from transition countries". In: Journal of Financial Intermediation 18(2), pp. 151 -172. ISSN: 10429573. DOI: http://dx.doi.org/10.1016/j.jfi.2008.04.002.

Djankov, Simeon, Caralee McLiesh, and Andrei Shleifer (2007). "Private credit in 129 countries". In: Journal of Financial Economics 84(2), pp. 299 -329. ISSN: 0304-405X. DOI: http://dx.doi.org/10.1016/j.jfineco. 2006.03 .004

Gehrig, Thomas and Rune Stenbacka (2007). "Information sharing and lending market competition with switching costs and poaching". In: European Economic Review 51(1), pp. 77 -99. ISSN: 0014-2921. DOI: http: //dx.doi.org/10.1016/j.euroecorev.2006.01.009. 
Ioannidou, Vasso and Steven Ongena (2010). "Time for a Change: Loan Conditions and Bank Behavior when Firms Switch Banks". In: The Journal of Finance 65(5), pp. 1847-1877. ISSN: 1540-6261. DOI: $10.1111 / \mathrm{j}$. 1540-6261.2010.01596.x.

Janvry, Alain de, Craig McIntosh, and Elisabeth Sadoulet (2010). "The supply- and demand-side impacts of credit market information". In: Journal of Development Economics 93(2), pp. 173 -188. ISSN: 0304-3878. DOI: http://dx.doi.org/10.1016/j.jdeveco.2009.09.008.

Jappelli, Tullio and Marco Pagano (2002). "Information sharing, lending and defaults: Cross-country evidence". In: Journal of Banking \& Finance 26(10), pp. 2017 -2045. ISSN: 0378-4266. DOI: http://dx.doi.org/10. 1016/S0378-4266(01)00185-6.

Karapetyan, Artashes and Bogdan Stacescu (2014). "Information Sharing and Information Acquisition in Credit Markets". In: Review of Finance 18(4), pp. 1583-1615. DOI: 10.1093/rof/rft031, eprint: http://rof . oxfordjournals.org/content/18/4/1583.full.pdf+html.

Padilla, A. Jorge and Marco Pagano (1997). "Endogenous Communication Among Lenders and Entrepreneurial Incentives". In: Review of Financial Studies 10(1), pp. 205-236. DOI: 10.1093/rfs/10.1.205, eprint: http: //rfs.oxfordjournals.org/content/10/1/205.full.pdf+html.

Padilla, A.Jorge and Marco Pagano (2000). "Sharing default information as a borrower discipline device". In: European Economic Review 44(10), pp. 1951 -1980. ISSN: 0014-2921. DOI: http://dx.doi.org/10.1016/ S0014-2921(00)00055-6.

Sharpe, Steven A. (1990). "Asymmetric Information, Bank Lending, and Implicit Contracts: A Stylized Model of Customer Relationships". In: The Journal of Finance 45(4), pp. 1069-1087. ISSN: 1540-6261. DOI: 10. 1111/j.1540-6261.1990.tb02427.x.

Thadden, Ernst-Ludwig von (2004). "Asymmetric information, bank lending and implicit contracts: the winner's curse". In: Finance Research Letters 1(1), pp. 11 -23. ISSN: 1544-6123. DOI: http://dx.doi.org/10.1016/ S1544-6123(03)00006-0. 